Portland State University

PDXScholar

9-27-1996

\title{
James Baldwin's Search for a Homosexual Identity in his Novels
}

Nadia Abdel Fattah

Portland State University

Follow this and additional works at: https://pdxscholar.library.pdx.edu/open_access_etds

Part of the English Language and Literature Commons Let us know how access to this document benefits you.

Recommended Citation

Fattah, Nadia Abdel, "James Baldwin's Search for a Homosexual Identity in his Novels" (1996). Dissertations and Theses. Paper 5231.

https://doi.org/10.15760/etd.7103

This Thesis is brought to you for free and open access. It has been accepted for inclusion in Dissertations and Theses by an authorized administrator of PDXScholar. Please contact us if we can make this document more accessible: pdxscholar@pdx.edu. 


\section{THESIS APPROVAL}

The abstract and thesis of Nadia Abdel Fattah for the Master of Arts degree in English were presented September 27, 1996 and accepted by the thesis committee and the department.

COMMITTEE APPROVALS:

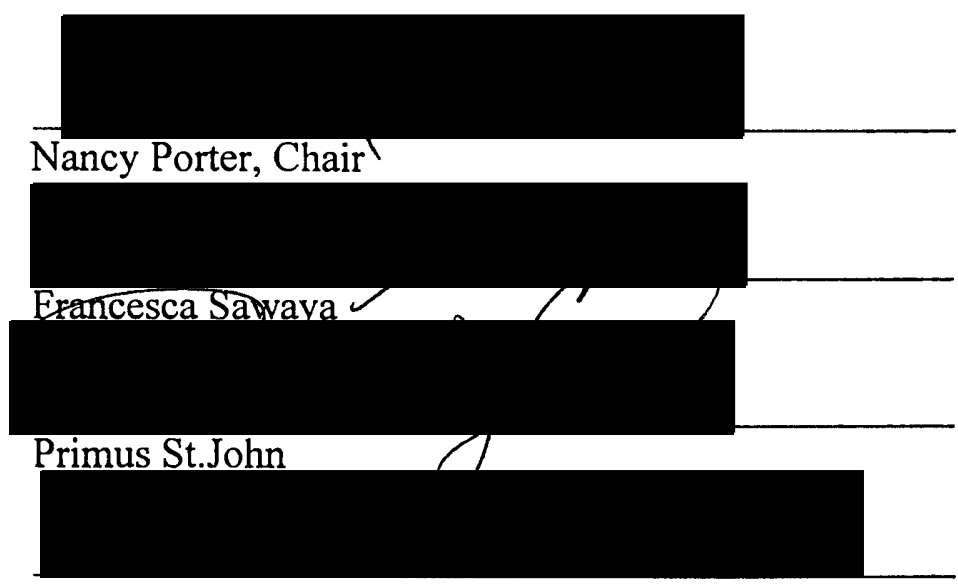

Lawrence Wheeler

Representative of the Office of Graduate Studies

DEPARTMENT APPROVAL:

Shelley C. Reeq $\$$, Chair

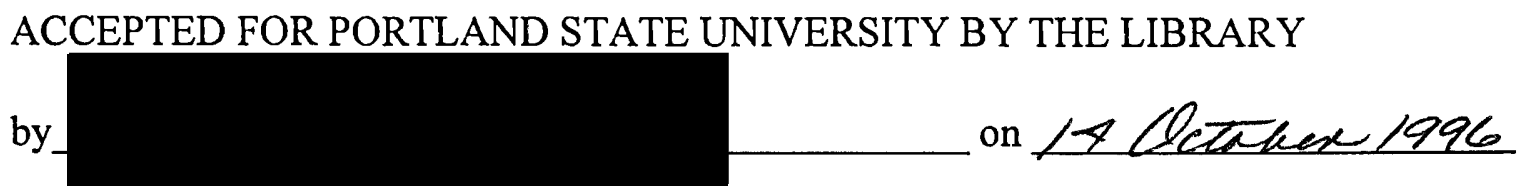




\begin{abstract}
An abstract of the thesis of Nadia Abdel Fattah for the Master of Arts in English presented September 27, 1996.
\end{abstract}

Title: James Baldwin's Search for a Homosexual Identity in his Novels.

James Arthur Baldwin (1924 - 1987) is one of the two major writers who have dared write about black gay men and from a black gay perspective. However, his fame as a racial spokesman and his insightful analyses of race relations in America tend to distract attention from the fact that he has been one of the most important homosexual writers of the twentieth century. Intolerance and homophobia among black and white Americans often led to a misinterpretation or misevaluation of James Baldwin's novels.

James Baldwin was very courageous to come out as a black homosexual writer during the period of the Cold War and the Civil Rights movement. However, his awareness of racism and homophobia in the American society, and his difficult position of being a public figure and a spokesman for the Afro-Americans left its traces in his novels and influenced his novel writing career.

The purpose of the present study is to show that out of intolerance, ignorance, and homophobia the evaluators of James Baldwin's novels often did him no justice. Baldwin through his novel writing developed a homosexual consciousness for himself. This struggle of coming-out was his personal struggle and it was marked by his burden of the 
doubly oppressed. I argue that Baldwin's search for an identity as a black homosexual writer is reflected in his writing. He constructed his identity through his writing.

This study attempts to show that Baldwin's development of a homosexual identity took place in stages during his novel writing career. An analysis of the novels Go Tell It On the Mountain (1953), Giovanni's Room (1956), Another Country (1962), and $\underline{\text { Just }}$ Above My Head (1979) will demonstrate his movement from dealing with homosexuality as an underlying theme to using it as a tool to protest against any kinds of labels in the American society. Baldwin believed that discrimination cannot cease as long as the categorization of people through artificial constructs such as the "Negro" or the "homosexual" exists. 
NADIA ABDEL FATTAH

A thesis submitted in partial fulfillment of the requirements for the degree of

\section{MASTER OF ARTS}

in

ENGLISH

Portland State University

1996 


\section{ACKNOWLEDGEMENTS}

I particularly want to thank my Thesis Advisor Nancy Porter for her encouragement, time, critical comments, and great ideas, but especially for her faith in me when I applied to the English program last year. Lawrence Wheeler and Primus St. John were critical and supportive readers of my thesis and motivated me in 'painful' times. I wish to thank my friend Nathan Tanner for his never ending-patience and his moral support as well as for his reading and commenting on many of my English papers. I also want to thank my friend Hamza Khayyat for numerous acts of kindness during this summer and Pushpak Mamnani for letting me use his computer. I am also indebted to Andreas Rechsteiner who fixed my computer many times in emergency situations. 


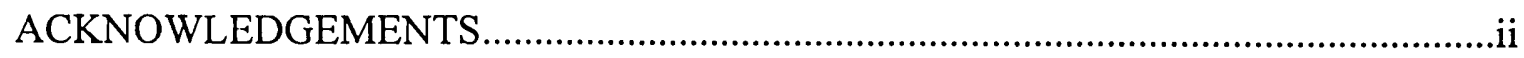

INTRODUCTION

CHAPTER

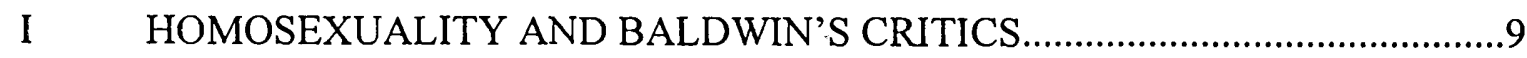

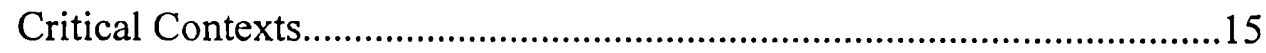

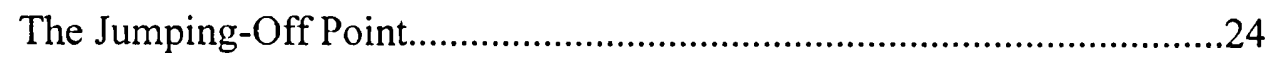

II GO TELL IT ON THE MOUNTAIN AND BALDWIN'S SEARCH FOR

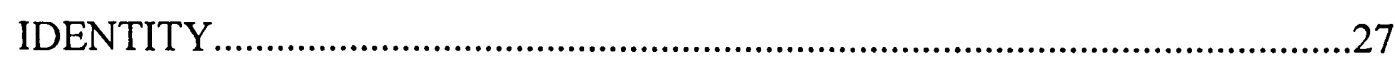

III THE BRIDGE TO GIOVANNIS ROOM …….................................................47

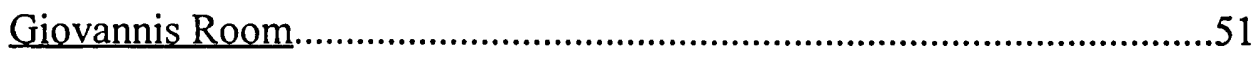

IV ANOTHER COUNTRY-- THE TURNING POINT ...........................................71

$\mathrm{V} \quad$ JUST ABOVE MY HEAD -- END OF THE JOURNEY .....................................

VI CONCLUSION: JAMES BALDWIN-- BALANCING THE PARADOX.........103

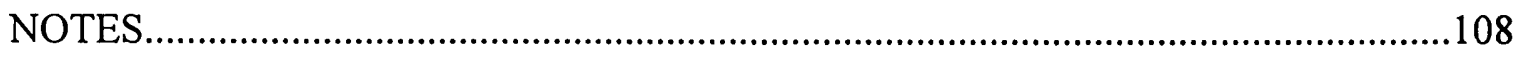

BIBLIOGRAPHY 


\section{INTRODUCTION}

When I first came across James Baldwin, I was in my teens, living in East Germany in an ideologically oppressed society. The East German people were indirectly manipulated by the government through the selection of movies, music, plays, and literature, as well as by distortion of present and past history and politics. The school curricula were uniformly designed from grade one through twelve and were based on a carefully selected assortment of literary and historical pieces, with the intention of molding us into young socialists faithfully obeying the ideology of the ruling socialist party. Of course, my peers and I were mostly unaware of our ideological formation. Certain policies, which often directly affected my family, like the inability to travel to Egypt to visit my father's relatives because the officials thought that we would not return, made me sometimes wonder, but we all passively accepted these regulations, "knowing" that they were necessary in order to protect us from our enemy, the capitalist West.

I grew up in a very intellectual family, with a strong affinity for reading, particularly nineteenth century Russian literature. Through lucky circumstances -- my mom wrote a friend from Egypt that she was yearning for good literature -- we also had in our home books by Lawrence Durrell, Henry Miller, and James Baldwin. Being taught in school mostly classic German literature and in high school, in particular, the literature of socialist realism, I was fascinated and simultaneously shocked at the writings of Baldwin whom I discovered at the same time I also discovered Henry Miller. Both spoke 
very freely about sexuality, a subject which I had never encountered in any of the readings I had done to that point, but which I later also observed in Lawrence Durrell's narratives.

Moreover, what fascinated me most about James Baldwin was his preoccupation with homosexuality and with race, two topics which were not discussed in our society. Through his sometimes harsh tone he touched upon problems unknown to us who grew up in a very sheltered surrounding, and he also simultaneously transmitted a picture of America divergent from what we were told by the media and in school.

Racial hatred was practically unknown in the German Democratic Republic (GDR); with the fall of the wall it has become a serious issue, growing out of false patriotism and economic problems that include imported labor. The most dramatic examples were that children in the former East Germany would sometimes shout at me and my family "Neger, Neger!" with the insensitivity, unawareness, ignorance, but also openness of children.

Homosexuality, on the other hand, was not only something people would gossip or laugh about out of ignorance or intolerance, which caused those who were lesbian or gay to carefully hide it, but was also equated with politically wrong behavior by the ruling socialist party, the SED, ${ }^{1}$ and homosexuals were discriminated against in my country. A German historian, Günther Grau, investigating the persecution of homosexuals during the Nazi era, also read in SED documents (Der Spiegel 76-77 ). ${ }^{2}$ He discovered that until $1968^{3}$ SED officials often literally adopted phrases of the Nazipropaganda to argue against homosexuals in the GDR. Even with the banishing of article 
175 of the constitution in 1968, discrimination against homosexuals in the GDR did not stop. The SED denied homosexuals the right to establish their own organizations or support groups, with the explanation that they could participate in the building of the socialist state, like other citizens with a different lifestyle, without the necessity of having their own organization. Thus, Grau explains, homosexuality was pushed into secrecy in the GDR because sexuality was used as a disciplining tool. The socialism as practiced by the ruling party did not permit any deviation from the picture of the good citizen. Grau concludes that like the Nazis, who wanted to shape the population to their desired norms, SED politicians also attempted to enforce a sexual norm among the East German people.

This surely is one of the reasons I have never known anybody with a different sexual orientation in Germany until very recently. Shortly before the wall came down in 1989, censorship loosened up a little in East Germany, and a movie called "Coming Out" created a lot of controversy. This movie told the story of two lovers, one of whom was married and reluctant to admit his homosexuality, which consequently drove his partner to a suicide attempt. It strongly reminded me of Baldwin's Giovanni's Room. What was so similar between these two works was the protagonists' conflict between following their natural sexual inclination or living a life "morally" acceptable to society. The audience in the movie theater laughed or uttered repulsive remarks at some sexual scenes between the two men; and I was myself somehow shocked at the natural depiction of two kissing and sexually engaged men seen through the eyes of the camera. Yet, the movie attracted many moviegoers, mostly because the subject matter was so unusual for its time. 
Back then I never even dreamed about the possibility of visiting the United States. Curious all my life about foreign countries and cultures, the closest thing I could do was to decide to study languages, Russian and English, knowing that at least I could go to Russia and study there for a while. The rapid political change in Germany, however, brought with it the freedom to travel, and in Winter 1994 I, along with fellow students, visited our new partner college in Nashville, Tennessee. Two weeks was a very short time for a visit to such a gigantic country as the U.S., and being without cars, we were mostly limited to the campus of Belmont University and the pretty boring downtown of Nashville. But that exposure was sufficient to let us feel a hint of racial tension. Because Belmont was a private university chiefly for elite students, we saw on the campus during that time only two or three young male blacks who had been granted scholarships for outstanding athletic achievements. On the other hand, the staff in the cafeteria and the cleaning staff were almost exclusively Afro-Americans. When asked during a German American night about the student population and other issues, we clearly felt the keen interest on the side of the professors in avoiding the topic of race. This experience revealed, though, just some surface tension, not even coming close to Baldwin's account of racial problems. And the issue of sexuality, so freely discussed in his novels and also by other contemporary American authors, was a taboo topic on this strictly Catholic campus, with separate dorms for males and females. So where could I find Baldwin's America? Or was it just a myth or a mere exaggeration born out of his mind? My next encounter with Americans was during that summer. A group of New York students came to visit my university and I volunteered to be a host to one of the 
students. During one night we, the Germans and the Americans, had a lively discussion about what it means to be German or American. Each one of us was asked to give his or her own definition. Some of the Americans spoke about their ancestors, their European roots, and their pride in being American. When it was my turn, I said that for me the most important thing was to be myself. In Germany I could not identify myself as truly German because, although I was born there, possess the German passport, and consider German as my mother tongue, I have always had the sense of being different. And whenever I am in Egypt, although always warmly welcomed and treated by the Egyptians as one of them, I also do not really feel like an Egyptian, because I am not able to communicate with them in my father's language and am too much westernized in dress and behavior and thus distinguishable from Egyptian women.

Thus, my "dilemma" of identity equals in a way James Baldwin's dilemma of identity -- we share the sense of otherness. People have often raised their eyebrows in amazement when, asked where I come from, I answer Germany. Seeing the disbelief in their eyes, I always feel compelled to add that my father is Egyptian, because I don't match at all the blond-haired, blue-eyed German stereotype. This is one of the reasons for my desire for traveling. I felt very comfortable in Russia and I have been very comfortable here because ethnicity does not seem to matter in these multi-ethnic and multi-cultural countries as much as it does in conservative Germany; rather, it creates curiosity. Also, like Baldwin who spent many years abroad, mostly in France and in Turkey, I have used traveling as a means of obtaining individuality and independence from the sometimes fairly restrictive up-bringing of my Muslim father. 
This sense of not knowing about one's identity, of trying to live an unrestrained life, brings me back full circle to James Baldwin, who was continually engaged in the quest of finding his "self" as a black male homosexual American.

Now I am in the U.S. again, this time not for two weeks but for two years. Fighting my way through the required coursework, I came across works in the canon aimed at determining national selfhood, manhood, womanhood, and race in constructing identities. Homosexuality was left out, though. Having encountered this issue here so often, however, either in talks with friends, or through jokes, movies, and in the newspapers, I felt the desire to take the chance and explore a still very controversial topic in the country famous for its freedom of speech.

James Baldwin's fame as a racial spokesman and his insightful analyses of the black experience in America tend to distract attention from the fact that he has been one of the most important and influential American homosexual writers of the twentieth century. Joseph Beam, who edited the black gay anthology In The Life, asserts that James Baldwin and Samuel R. Delany are the only two major writers who have dared write about black gay men and from a black gay male perspective (185). However, Baldwin's reputation rests chiefly on his fiery essays on race relations in which he wrote incisively about the Civil Rights movement and the relations between black and white Americans. I think that James Baldwin was a phenomenon to come out as a homosexual in the 1950s when it was not common. I have been deeply impressed by his courage to write about homosexuality during a time largely hostile to this topic and despite the threat to his career. In my opinion it was not fair to discredit him as a racial spokesman and 
gifted fiction writer as some critics and militant Afro-Americans did simply because he was a homosexual who continuously attempted to link racism and sexism in his fiction. Inspired by the critic, Emmanuel S. Nelson, who suggests in his essay, "The Novels of James Baldwin: Struggles of Self-Acceptance," that Baldwin's homosexual consciousness developed in stages, I would like to explore how he carried his struggle for a sexual identity, and his eventual coming to grips with his gayness, into his fiction by means of style, themes, structure and tone. In my opinion, James Baldwin's fiction illustrates what Diana Fuss describes as the "tension between the notions of 'developing' an identity and 'finding' an identity" (qtd. in Bergman. Gaiety Transfigured: 4). This tension, which David Bergman explains as resulting from the two stages of coming-out -the individual's process of accepting himself as being homosexual and secondly, of integrating his homosexuality into his life (4) -- is echoed, I will argue, in Baldwin's novels. That he constantly picked up the topic in his fiction indicates to me that he was permanently contending with it. I suggest that the four novels I am going to explore symbolize Baldwin's struggle to construct an identity as a homosexual writer and represent the process of integrating homosexuality within the larger context of his mission as an Afro-American spokesperson and fiction writer. I would like to demonstrate that Baldwin's search for a sexual identity is reflected in his writing and that the acceptance of his sexuality took place in stages during his writing career. In Go Tell It On the Mountain (1953), his first novel, he deals with homosexuality indirectly. In Giovanni's Room (1956) Baldwin openly tells the world about his homosexuality, but yet does not come to a healing acceptance of it. Another Country (1962) represents a 
polemical confrontation with homosexuality, whereas Just Above my Head (1979) reflects his acceptance of homosexuality through the representation of its naturalness. In the first chapter of my thesis I will present a brief overview of homosexuality in the United States from roughly the beginning of Baldwin's career as a fiction writer in the early 1950 s until the publication of his last novel, Just Above My Head, in 1979. In Chapter I I will also discuss the critical context concerning James Baldwin's fiction and will try to illuminate the reasons for the mixed reception his novels have received.

Chapter II, Chapter III, Chapter IV, and Chapter V will deal respectively with the novels Go Tell It On the Mountain, Giovanni's Room, Another Country, and Just Above My Head to demonstrate the development of Baldwin's homosexual identity in his literary imagination. The concluding chapter, Chapter VI, will discuss Baldwin's larger mission as an Afro-American homosexual writer. 


\section{CHAPTER I}

\section{HOMOSEXUALITY AND BALDWIN'S CRITICS}

In the year 1948, five years after James Arthur Baldwin ( 1924 - 1987) had started working on his first novel, Go Tell It On the Mountain, the Kinsey report on Sexual Behavior in the Human Male was published in the United States. Ironically, by the time Baldwin finished the novel five years later, Kinsey's progressive ideas about homosexuals had already been discredited by conservative psychologists. According to Claude J. Summers in Gay Fictions: From Wilde to Stonewall, the Kinsey report became a best-seller for its straightforward and non-moralistic discussion of sexuality in America. The report discussed the heretofore repressed subject of homosexuality in the U.S. and revealed a surprisingly large occurrence of homosexuality among Americans. ${ }^{4}$ As Summers explains, this publication in the late 1940s gave homosexuals in the United States for the first time the sense of belonging to a larger group (24).

The great residential mobility and economic boom in the United States after World War II had led to a wider recognition of homosexuality; yet this "postwar permissiveness" drastically receded during the Cold War period (Levin 61). The aggravating fear of Communism helped to stifle all unconventional ideas in the U.S. Claude J. Summers, James Levin, and others report an increased homophobia during that time in which homosexuals became the scapegoats of the Cold War and were more aggressively and systematically attacked than ever. Levin explains that in 1952, with a 
shift to a Republican presidency after twenty years of liberal Democratism, several very conservative members from both parties were elected to Congress. The most influential was Senator Joseph McCarthy. McCarthy skillfully used the general fear of Communism against homosexuals whom he labeled deviates and associated with Communists and intellectuals (Levin 110). Thus, during this period in the 1950s, homosexuals suffered a widespread harassment by local and national police organizations and thousands of them were arrested and imprisoned for homosexual offenses (Summers 26). Samuel R. Delany, a black science fiction writer who was born in 1942, remembers the situation he witnessed during the Cold War era:

Today, with the Annual Gay Pride Day March, and a widely distributed gay press, and the Phil Donahue Show, we forget the biggest fear we used to have as gay men, in the forties and fifties, black or white, was of someone's finding out: anyone who knew you were gay...had life and death power over you. That person could lose you your job, get you evicted, or have you generally hounded out of town. The House UnAmerican Activities Committee was hunting up gays right along with Communists back in the early fifties -- because we were more susceptible to blackmail, and therefore bigger security risks. ( qtd. in Beam: 186)

Summers summarizes that the popular image of homosexuals as immoral, emotionally unstable, and untrustworthy served as a justification for their punishment and stigmatization. Furthermore, he explains, in an era with an increasing stress on the home 
and family values, homosexuals were perceived as a threat to the family, and in churches homosexuality was treated as a dreadful moral lapse (26).

The field of psychology, which developed rapidly and became very popular in the United States in the 1950s, derived much of its theories, according to Levin, from the Austrian psychoanalyst, Sigmund Freud. Freud did not consider homosexuality as genetically caused but as an abnormal development, based on environmental influences. Eve Kosofsky Sedgwick in her book Between Men describes the Oedipal triangle theory which Freud established (22). According to Sigmund Freud, homo- and heterosexual outcomes in adults are the result of a complicated play of a child's desire for and identification with the parent of each gender. A little boy developing toward heterosexuality must pass through the stage of the "positive" Oedipus, "a homoerotic identification with his father, a position of effeminized subordination to the father, as a condition of finding a model for his own heterosexual role" (Sedgwick 23). In this theory the development of the male homosexual assumes the absence of or distance from the father and an abnormally strong identification of the child with the mother, in which the child takes the place of the father (Sedgwick 23). Homosexuality was thus seen as normally a temporary and transitional stage in Freud's theory and only a prolongation of this period in some people constitutes its abnormality. Although Freud was ambiguous about the efficacy of psychoanalytic treatment, he generally held the belief that attempts to change one's orientation would be ineffective (Levin 111). Many of Freud's followers, though, considered homosexuality as "arrested sexual development" and 
classified it as a mental illness which could be cured through psychoanalytic treatment (Bergman 37).

While psychoanalysis was not widely accepted in Europe, it received great recognition in the U.S. Sherry Turkle explains the causes for this trend in her book Psychoanalytic Politics. Turkle distinguishes between a "French Freud" and an "American Freud" resulting from the greatly differing perceptions of his theories in France and the U.S.. Turkle reports that Sigmund Freud was amazed at the enthusiasm with which Americans welcomed psychoanalysis in contrast to Europeans. He remarked that "in prudish America" it was possible to discuss everything that was normally regarded as objectionable in a scientific manner (4). Freud warned against the too easy acceptance of the medicalization of psychoanalysis as it had happened in America. The reasons for this process were, according to Turkle, a combination of optimism, individualism, and voluntarism which laid the foundation for the acceptance of a psychoanalytic therapy, resting on the assumption that people can change themselves by their own efforts, if they wish to do so. Traditional French ideas about individualism, on the other hand, focus on the individual's boundaries and isolation from others, according to Turkle. She argues that the American belief system relies on the "plasticity of the individual who could learn to conform" (7) if he wants to achieve success. Turkle makes it clear that the American version of Freudian psychoanalysis was able to lessen fears of being different or of being unsusceptible to "reform", and it promised that selfimprovement was possible without calling society into question (7). An important reason for Freudian acceptance in the U.S. was that America was marked by great mobility and 
instability following World War II, and in times like these, Turkle argues, individuals in search for meaning in life were often more receptive to theories such as psychoanalysis $(31)$.

This psychoanalytic trend added to the increasing intolerance against homosexuals among the population because. Intolerance was considered an incentive for homosexuals to change to heterosexual behavior. Any resistance of the homosexual against "cure" was seen as further proof of mental imbalance since a moderately ill person was assumed to be healthy enough to recognize his need for treatment in order to become "normal."

David Bergman in Gaiety Transfigured recounts another publication of the very influential psychoanalytic school, the Irving Bieber report, Homosexuality: A Psychoanalytic Study, which was published in 1962 as an official report of The Society of Medical Psychoanalysts (190). This report also codified a strong mother/weak father theory of homosexuality and asserted that "all parents of homosexuals apparently had severe emotional problems. The homosexual son emerged as the interactional focal point upon whom the most profound parental psychopathology was concentrated" (Bieber's italics) (qtd. in Bergman. Gaiety Transfigured: 190).

President John F. Kennedy's election in 1960 marked the beginning of a decade of changes and challenges. A climate that permitted the questioning of social and political values developed and within this climate older ideas about homosexuality were also challenged (Levin 175). Levin explains that the ideology of the emerged counterculture celebrated love as the greatest virtue -- the antidote to materialism and war 
-- and there was no reason that this should not apply to homosexual love. Those who rebelled against the bourgeois values found homosexual men natural allies because gay men had automatically been excluded from bourgeois life. As a result, in the early 1960 s the virulent homophobia of the McCarthy era lessened somewhat and social activist groups changed into political groups insisting on the recognition of gay and lesbian people as a minority group that deserved equal treatment in a pluralistic society (Summers 27).

Despite the social and political ferment of the sixties, which had some influence on general ideas about homosexuality within the larger society, a general non-acceptance of homosexuality still prevailed. Events escalated in June 1969 in a gay bar, the Stonewall Inn Bar, in New York's Greenwich Village (Levin 247). Summers reports that on the night of June $27-28,1969$, a police raid in the Stonewall Inn, conducted to interrupt same-sex dancing, ignited three days of rioting by gays and lesbians, suppressed only by the extra efforts of special police riot squads. This event, Summer declares, inspired the birth of gay liberation as an international mass movement. The newly militant gay movement challenged stereotypical ideas about homosexuality and demanded social and political equality for lesbians and gays (Summers 16$){ }^{5}$

In the climate of more militant advocacy following Stonewall, research discredited Bieber's model of homosexual origins. Studies showed repeatedly that there were no discernible differences in psychological adjustments between homo- and heterosexuals. In 1973 the American Psychiatric Association finally decided to declassify homosexuality as a mental illness ( Summers 235). 
Legislative efforts to ensure gay and lesbian civil rights, the establishment of support groups, the founding of publications, and an upswing in the production of movies and books have created a climate of greater tolerance toward homosexuals. Referring back to James Baldwin, this tolerance or at least willingness to acknowledge homosexual concerns has become visible in the more positive evaluation of his fiction which, in particular, in the 1950s and 1960s had been based on a homophobic point of view by many critics as I shall show in the next paragraph. However, homophobic opinions of friends, or anti-gay political acts such as Measure 9 and Measure 13 put on the ballot by the Oregon Citizen Alliance in 1992 and 1994 respectively, have convinced me that there is still today a widespread ignorance of homosexuality and homophobia among the general population. American society still struggles with issues James Baldwin insightfully addressed in his essays and his fiction many years ago -- issues of love, tolerance, humanity, and human rights.

\section{Critical Contexts}

When James Baldwin was asked about his "dilemma" of being black and being homosexual in an interview in the 1980s, he responded that he saw his "dilemma" as an advantage: "I thought I hit the jackpot" (video: $\underline{\text { James Baldwin: The Price of the }}$ Ticket). However, Baldwin's late in his career identification with these two categories makes it difficult to interpret his earlier stance as the author of controversial novels such 
as Giovanni's Room or Another Country, considering the socio-political climate in America at the time of their publication. I want to argue that Baldwin can be read in at least two ways: He is a homosexual writer in search of an identity and self-acceptance, and he is also a writer who wanted to be socially accepted and thus as late as 1984 pointed out that Giovanni's Room, a novel which tells about the coming-out experience of a homosexual, is not really about homosexuality but the universal theme of love (Goldstein 176).

Thus, given Baldwin's complexities -- his sexuality, his ethnicity, his reputation as Afro-American spokesman, his constant implementation of autobiographical elements in his novels, and the politically difficult time period of his writing career -- it has been hard for the critics, and also for me, to understand and evaluate James Baldwin's novels.

Baldwin always objected to writing for a certain audience. Louis H. Pratt assesses that Baldwin refused to align himself with the Black Arts Movement, which emerged under LeRoi Jones's guidance in the 1960s. Baldwin resisted the acceptance of the term "black writer," which sought to create an aesthetic based on the idea of " a black man talking to other black men, not talking simply to an audience of middle-class, credit-card carrying whites" (Pratt 16). Baldwin also disdained being considered a homosexual writer because that would as well suggest limits on his individuality, as Stephen D. Adams in The Homosexual Hero in Contemporary Fiction explains (35). He continued to call himself an "American writer" and thus continued to confront the issues facing a multi-racial society (Black Literature Criticism 76). As Seymour Krim in his essay, "The Troubles He's Seen," assesses: "He has almost always tried to dig into the humbling soil 
of the experience of the Negro, the expatriate, the homosexual, and come out with uneasy, disturbing truths...."(5).

Baldwin as a black and a gay writer had to deal with the wrath he and other homosexual blacks suffered from heterosexual African-Americans. A. Billy S. Jones ${ }^{6}$ in his essay, "A Father's Need; A Parent's Desire," explains that the civil rights movements of the fifties and sixties had given blacks a sense of pride about their blackness and their culture. He says that although the gay civil rights movement had modeled much of its strategies after the black civil rights movements, few blacks before the seventies had heard of gay pride or understood the demands of gay activists. To blacks, he explains, the gay movement looked like a white trip with a few misguided blacks tagging along for the ride ( qtd. in Beam: 143).

Moreover, A. Billy S. Jones explains the particular difficulty of being black and being gay, stemming from the black community. He says that in the thinking of many black men and women being gay is somehow the opposite of being a man. Thus, a strong sense of nationalism and separatism, which often does not embrace homosexuality, can make the life of black homosexuals miserable. Moreover, black-white sexual relations, although legal, were still tolerated by only a few:

The means by which we cope with our Blackness in mainstream America does not give us the means for coping with our gayness. Just because Black Americans have a history of being discriminated against, of being victims of institutionalized racism, does not automatically free us from other forms of prejudice nor give us an understanding of the oppressions 
and injustices waged against others - even other Black gays.... A strong sense of Black nationalism or separatism, which often does not embrace homosexuality, will give some of my children's peers enough reason to make their lives miserable. (qtd. in Beam: 150)

Jones' words give an account of the situation Baldwin had to face as a black homosexual after his publicly 'coming-out' and writing fiction that dealt with homosexual issues, and, beginning with his novel Another Country in 1962, also with interracial issues. Daniel Garrett in "Creating Ourselves: An Open Letter" explains the complicated situation of an Afro-American homosexual as late as 1984:

As black gay men, we are charged with fighting the oppressions we know most about, our own. The white community has made blacks into strangers: creative, exotic, passionate, violent; and the black community has made black gay men into strangers: emasculated, sensitive, weak. These are myths which were born of historical insecurity. Whites conditioned by coldly objective, morally suspect European thought and culture. Blacks conditioned by slavery, continuing fears of castration -gays being ranked near women, women being despised in patriarchal society. (qtd. in Beam: 102)

In trying to distinguish Baldwin's critics it can be said that many black critics were thus often embarrassed and angered by Baldwin's explicit treatment of homosexuality, although they were often enthusiastic about his handling of racial themes. 
This evaluation does him no justice, though, because the disputed novel, Another Country, which deals with homosexuality and inter-racial relationships, became Baldwin's best-selling book. Although many critics publicly discredited the novel, it reached a broad audience. Daniel Garrett, a black homosexual, names it among his favorite books. He says that he loves contemporary works like Another Country because they question "ideas and realities of cultural relativism and imperialism, economic exploitation, gender roles, racial oppression and sexual orientation" (qtd. in Beam: 96). And Garrett admires Baldwin, the person, because he has "continuously testified to his own complexity, his own vision, and for this reason I've found him to be a great resource....I can only respect [people] for the stands they have made, and are making" (qtd. in Beam 99).

Many white critics seem to be uncomfortable responding to a writer like James Baldwin who is doubly different. Some positively assess his stance on racism but ignore the homosexual theme or discredit his novels for homophobic reasons. On the other hand, gay critics tend to privilege his sexuality over his ethnicity, whereas black critics overemphasize his ethnicity to the exclusion of his homosexual themes.

Most critics have agreed that Baldwin is a better essayist than he is a novelist. This appears to be closely related to the fact that Baldwin hardly dealt with issues of homosexuality in his essays, while he seemed to be obsessed with homo-, hetero-, and bisexuality in most of his novels. Beginning with the publication of Giovanni's Room in 1956, Baldwin created much turmoil with his fictive work. While many Americans were ready to publicly discuss racial conflicts in the late 1950 s and 1960 s, they were not 
prepared to deal openly with homosexual issues. In Another Country, in particular, the critics were not only overinfluenced by the sexual scenes, but also by the interracial relationships which were still rare in American literature or life at that time.

Basically, I would argue that James Baldwin's critics have taken five positions. First, there are critics who are positive about Baldwin's handling of racial issues in his novels, but ignore the sexual issues. Seen in this light, we might understand the silence that surrounded Baldwin's first novel Go Tell It On the Mountain with regard to homosexuality. Almost every reviewer when discussing the novel omitted its homosexual content, focusing instead on its racial importance. An explanation for this could be that Baldwin's very subtle suggestion of homosexuality in Go Tell It On the Mountain blinded the reviewers who lacked -- or denied -- any sensibility and consciousness of homoeroticism. On the other hand, however, the critics' silence could also be interpreted as an expression of homophobia, intentionally ignoring the author's masterful description of a young adolescent's developing homosexual consciousness in an era in which it was perceived as a sickness. Emmanuel S. Nelson in his essay, "Critical Deviance: Homophobia and the Reception of James Baldwin's Fiction," considers silence as the perhaps most harmful kind of homophobia which even continued after Baldwin's death. I agree with Nelson that this is evident in Toni Morrison's and Amiri Baraka's (LeRoi Jones's) eulogies which mourn the loss of a great black writer who fought against racism his entire life, but omit mentioning Baldwin's struggle against "sexual fascism" and his central place in gay literature (95). Nelson also explains that the silence around Baldwin's achievement as a homosexual writer continued during a 
symposium at the University of Massachusetts held in 1988 as a tribute to his life and work. Except for a comment that Baldwin spoke about sex "openly and honestly" the distinguished panel of speakers made no reference to his achievement in this field (95).

Second, some reviewers and critics outrightly display homophobia. Whitney Balliet, for instance, in her essay "Wrong Pulpit" (1962) declares that she feels appalled by the graphic and frequent presentation of sexual scenes in Another Country, especially because they are generally between white males or white and black males. Richard Gilman (1979) considers it a "disagreeable task" to review Just Above My Head because the book has an "apologia for homosexuality that seems quite unrelated to the rest of the novel" (30). Other critics that reveal a homophobic position toward Baldwin's novels are, for example, Robert A. Bone (1965), who condemns Baldwin for what he calls "the prospect of salvation through sodomy" (238), James Ivy (1957), David Littlejohn (1966), or Patrick Cruttwell (1963). One example of public homophobia reached Baldwin in the form of a letter, written to him by a young teacher from Montana State University in 1968. David Leeming tells in the Baldwin biography that this young man had been called a "smut peddler" for wanting to teach Another Country and that the university had then banned the novel from the classroom (200).

Third, some black militants, in particular, Eldridge Cleaver, were especially outraged at Baldwin's involving a black character in homosexual activities in Another Country -- a characteristic that was attributed first and foremost to white men. Cleaver in his essay, "Notes on a Native Son" (1966), declares homosexuality to be a crime worse than "baby-rape" (55). Rufus Scott, the male black protagonist, is in his words a 
"pathetic wretch" (55) and has nothing to do with the way Negroes have managed to survive the hell of America. Cleaver attacked Baldwin for muddling the issue of racial equality by the comparison to homosexuality. He wrote that Baldwin's homosexuality precluded him from being a proper spokesman for blacks. He and other militant AfroAmericans did not want a 'faggot' to be their racial spokesman. Shelton Waldrep, in his essay “"Being Bridges': Cleaver/ Baldwin/ Lorde and African-American Sexism and Sexuality", observes that Eldridge Cleaver, through his discrediting of James Baldwin in his book Soul on Ice, fitted into the intellectual macho cult of Norman Mailer, LeRoi Jones, and William Burrough that was predominant during the 1960s. They held the general belief that men must be strong and suppress their feminine side in order to protect themselves from the weakness and decay that comes from age, women, and gay men. Cleaver, in particular, according to Waldrep, demonstrated throughout his book his belief in the racist idea that male African-Americans must be primarily physical and therefore in a constant battle for masculinity, as they can be emasculated not only by women and homosexual men, but also by envious white heterosexual males who want to take possession of their sexual power. Waldrep summarizes Cleaver's position: "Therefore: an African-American/ male/gay/ intellectual is the antithesis of a true African-American man, the nemesis containing all of the wrong traits and desires" (171). It is thus not astonishing that Eldridge Cleaver, who highly valued Baldwin's essays on racial affairs, nonetheless discredited him on the basis of homophobia and a misreading of Baldwin's sophisticated fiction. 
Fourth, some gays discredit Baldwin as a homosexual writer, because he often employs bisexual characters. Samuel R. Delany, a black gay writer himself, and Joseph Beam, the editor of In the Life: A Black Gay Anthology, judge Baldwin's portraits of homosexuals as far from affirming (qtd. in Bergman. Gaiety Transfigured: 166). David Bergman concurs with Delany in that he also considers it a misrepresentation to call Baldwin's works homosexual because Baldwin carefully made all his fictive characters bisexual, and intentionally steered the reader away from specifically gay interpretations of his works through public remarks given in interviews, etc. (qtd. in Bristow: 150). ${ }^{7}$ Mark Lilly declares in his book, Gay Men's Literature in the Twentieth Century, that Baldwin repeatedly displays an especially repellent kind of internalized homophobia. Lilly sees this accomplished by Baldwin's rejection of the effeminate which is supposed to be a plea to the straight majority to be accepted as normal. ${ }^{8}$ Giovanni's Room lacks the coherence of Another Country in Lilly's opinion, and he says that while it is supposed to be about bisexual anguish, it often appears to be about the anguish of a gay novelist indirectly "coming-out" through the thoughts and deeds of his protagonist. The gay community traditionally regarded bisexuality as a "half-way house" when someone cannot face a complete coming-out and adopts the compromise of bisexual desire, according to Lilly. Thus, in his opinion, Baldwin is not honest and displays a selfindulgent and false or at least displaced anguish in this novel (165).

Lastly, a more positive assessment of Baldwin's novels emerged with an increasing tolerance and acceptance of homosexuality and homosexuals in the eighties. Adams (1980), for instance, sees the significance of Another Country not in 
homosexuality itself, but in its function of leading away from everyday classifications of people toward individual worlds. Lorelei Cederstrom declares in her discussion of Another Country in 1984 that Baldwin's ideas in the areas of love and sex are the most revolutionary. Baldwin demonstrates in Another Country that racial and sexual politics are intricately related and derive from the same sources. His use of sexuality provides a keen and incisive view of the state of human relationships in contemporary America. Carolyn Wedin Sylvander (1980) assesses that meaning and potential were given to the homosexual experience in Giovanni's Room and Another Country. Edmund White and Julie Nash gave very positive assessment of Just Above My Head after its publication in 1979.

The Jumping-off Point

Out of discomfort, ignorance, misreadings, and homophobia, the evaluators of Baldwin's novels often did him no justice. One might conclude from the criticism he received that he was caught in the dilemma of being gay for some people versus not being truly gay or gay "enough" for some others. This is where I would like to jump in with my own reading and prove that a lot of the criticism is off the mark because James Baldwin through his novel writing developed a homosexual consciousness for himself and this struggle of coming-out was his personal struggle reflected through different stages in his writing career. 
Although James Baldwin's works frequently feature gay characters, they are not specifically gay fictions but generalized representations of love and loneliness in which homosexual yearning is treated with the same dignity and rendered with the same pathos as any other form of love. His literary imagination and fiction are more and more driven by the thesis that homosexuality is a normal variation of human behavior, and the thesis is daring because it so calmly reveals a simple but profound truth about human sexuality. Again and again Baldwin exposes the falseness and ignorance of the larger American society and suggests that the homosexual experience is valuable in its own right.

Homosexuality in Baldwin's novels, which he, beginning with Giovanni's Room, always presents straightforwardly, seriously, and unapologetically, includes experiences of alienation and isolation. His novels mirror the recognition of the profound effect of stigmatization upon individuals. The difficulties of the coming-out process illustrated in, as well as through, his novels have much less to do with the individual's acceptance of homosexual desire than with adjusting to the social stigma -- not to mention actual physical danger -- attached to homosexuality. All of the novels reveal Baldwin's interest in social context and political issues; they give an account of his particular dilemma, while they also exhibit the social reality, cruelty, and oppression suffered by gay people in mid-century America. Moreover, his works contain the message that the oppression of the homosexual and the victimization of the Afro-American people are not easily distinguishable. Thus, Baldwin's homosexuals do not enforce but breakdown boundaries and hierarchies. Central to his vision is a wisdom that accepts the human being in all its variety. His own life had repeatedly shown him and taught him that the heart has reasons 
for doing things of which the mind is not aware. Precisely because he views homosexuality as a fully human variation, he writes about it with a naturalness and insightfulness that was highly unusual especially in the 1950s and 1960s. 


\section{CHAPTER II}

\section{GO TELL IT ON THE MOUNTAIN AND BALDWIN'S SEARCH FOR IDENTITY}

Throughout his life Baldwin was obsessed with questions of identity. What does it mean to be a black American? And what does it mean to be a homosexual?

Although I consider Baldwin to be one of the most important homosexual writers of the twentieth century, I realized through my research that his novels, apart from Giovanni's Room, have hardly been read in an explicitly gay light. The obvious public discomfort with this side of him became apparent even at his funeral in December 1987 where, as one critic remarked, his achievement as a homosexual writer was not mentioned in the speeches honoring and remembering him.

In order to support my contention that Baldwin is a homosexual writer, as opposed to a writer who happens to be gay, I will refer to the theory of David Bergman who, in Gaiety Transfigured, outlines four characteristics which distinguish the structure of the discourse of homosexual experience from other sexual discourses (30):

1. A profound sense of otherness is the most significant term that affects the homosexual. The homosexual suffers a categorical otherness which often leads to a negativity of the self because the homosexual is never raised as such and finds no likeness in the family circle. In fact, the family prompts the homosexual's awareness of his "unlikeness."

2. Homosexuality is not just a phase; it is a lifelong condition. 
3. Homosexuality is characterized by a genuineness of experience in that the homosexual's desire for men is felt as genuine, whereas he often identifies heterosexual activities as "shallow" or "false" or "pretended".

4. Lastly, homosexuality is marked by the equality of its relations. This means that no specific roles are assigned to specific individuals. In contrast, a remarkable fluidity of roles can be observed that cuts across racial, social, and cultural boundaries.

Through showing that these characteristics might be found in Baldwin's novels

Giovanni's Room, Another Country, and Just Above My Head, I want to argue that James Baldwin was a genuine homosexual writer and that ignoring his talent and strength as a gay novelist leads to a limited apprehension of the complexities of his novels and his personality.

I intentionally did not include Go Tell It On the Mountain in the above mentioned listing, although the reader encounters there some of Bergman's characteristics of the discourse of homosexual experience, because, in my opinion, Baldwin was still very hesitant about the homosexual experience at the time he published his first novel in 1953. I derive my assumption from Baldwin's essay "The Male Prison" (1954) in which he analyzes the novel Madeleine by Andre' Gide. Baldwin is there concerned with the two sides of Gide's personality and the balance between them. On the one hand he notes Gide's Protestantism, his purity, and his otherworldliness, which found expression in the Platonic, not sexual, love he had for his wife, Madeleine. On the other Baldwin notes Gide's homosexuality and his lust for the boys on the Piazza d'Espagne. Baldwin says about Gide's homosexuality: 
... his homosexuality, I felt, was his own affair which he ought to have kept hidden from us, or, if he needed to be so explicit, he ought at least to have managed to be a little more scientific -- whatever, in the domain of morals, that word may mean -- less illogical, less romantic. (Nobody Knows My Name 156)

Baldwin criticizes Gide for separating sex and love in his life, for the irresponsibility of his homosexuality and his attempt to have his pleasures without "paying" for them. Simultaneously he displays in "The Male Prison" his personal fear of the ostracized position of the homosexual in a heterosexual society. This is why Baldwin evaluates the ongoing debate about the naturalness of homosexuality in the 1950s as "pointless" (157), knowing that the answer to this question can never be YES because it would rob the heterosexual majority of its necessary sense of security and order. It is a fact, he says, that the world is made for a communion between men and women and for this reason one needs to "keep the door of possibility open" (161) to enter into communion with another sex. "This door, which is the door to life and air and freedom from the tyranny of the one's own personality, must be kept open, and none feel this more keenly than those on whom the door is perpetually threatening or has already seemed to close" (160; Baldwin's italics).

I learned from Baldwin's biography that the time he wrote Go Tell It On the Mountain and "The Male Prison" he knew that he was gay and had been involved in several love affairs with men. Yet, at that time he felt that he needed to keep the 
possibilities of heterosexual relations open because adding his despair to the general woe would be counterproductive.

Baldwin affirms this position in an interview he gave to his first biographer, Fern Eckman, in 1966. Asked about the meaning of his commentary on Gide's homosexuality, Baldwin responded that it was meant as a commentary on himself. "I was accusing myself...of a certain fear and a certain hypocrisy" (135). However, Baldwin's main point in this essay is that the creation of "prisons" of various kinds makes love impossible.

Although, he highly admires Andre' Gide's honesty and courage to write so frankly about homosexuality, Baldwin himself was careful to stay within "the domain of morals, [whatever] that word may mean" (156). And for this reason, I reckon, he is hiding in the closet in Go Tell It On the Mountain, the first book I am going to discuss in detail.

Like most of Baldwin's works, Ge Tell It On the Mountain is strongly influenced by autobiographical events which reflect the author's quest for an identity. I am particularly interested in Baldwin's search for a homosexual identity which has mostly been de-emphasized by scholars and critics in the discussion of the phenomenon of Baldwin. It is the first work I am going to analyze in order to show the impact of his homosexual consciousness on his fiction. Baldwin had worked for almost ten years on this novel and he eventually finished it in a small Swiss village four years after he had left the United States for the first time. The long time period in which Baldwin worked on Go Tell It On the Mountain was characterized by sexual ambivalence, many unstable or 
unsuccessful love relationships, suicide attempts, and his inability to come to grips with his homosexuality. I want to argue that we can find homosexual elements in Go Tell It On the Mountain; yet they are repressed, resulting from a reluctance on Baldwin's part to deal openly with homosexuality at that time. In short, I see that Go Tell It On the Mountain embodies the first of the two stages of the coming-out process as described by Diana Fuss: it is a depiction of the individual in the process of coming to accept himself as homosexual.

Go Tell It On the Mountain (1953) recounts the story of a black boy, John Grimes, growing up in Harlem, who is on the threshold of his fourteenth birthday. Within the time span of two days we are told the agony of John who is seeking to know himself in the new demands of his adolescent mind and body. The first part of the novel, The Seventh Day, and the finishing part, The Threshing Floor, are told through the eyes and voice of the adolescent John. The middle part of the book, The Prayers of the Saints, depicts the stories of John's mother, Elizabeth, his stepfather, Gabriel, and his aunt and stepfather's sister, Florence, as they recount their past on this memorable evening in church. It is a special night because it is the night of John's conversion; when he leaves the church on the next morning he is saved and one of the 'saints.'

Go Tell It On the Mountain vividly depicts the situation and the problems of the Afro-American who came during the great migration to the North; it describes the agony of growing up or living in New York's Harlem, and the ambivalence of black churches. Being aware of the multitude of issues James Baldwin tackles in this novel, I want to specifically focus on the theme of homosexuality and consequently deal primarily with 
parts one and three of the book. However, where it seems relevant to me to show connections to John's present, I will refer to The Prayers of the Saints, which represents the Afro-Americans' historical burden in a wider sense and their special impact on John in a narrower sense.

Baldwin has been known as a master of incorporating his rhetorical abilities in his written works, stemming from his time as a boy preacher. Thus, he brilliantly uses an excerpt from the Old Testament (Revelation 22:17) as epigraph to Go Tell It On the Mountain as a means of foreshadowing the novel's problems, and more precisely, John's internal struggle. Nagueyalti Warren, in his essay "The Substance of Things Hoped For," reads this epigraph as not only rife with irony but also as a prophecy for self-acceptance (21).

And the Spirit and the bride say, Come.

And let him that heareth say, Come.

And let him that is athirst come. And whosoever will, let him take the water of life freely. (9)

At the beginning of the novel, John is torn between the decision to become a preacher like his father and the prospect of a life that could be different from his gloomy and poor home. This decision has also further implications with regard to his sexually awakening body in a church which rigidly oppresses any sexuality. Thus, he is being called by the church as well as by a secular lifestyle. I would suggest that the epigraph also contains some homosexual references since we do not know whom the 'Spirit' or the 
'bride' calls, man or woman. They call everybody "that heareth" and everybody "that is athirst" to be unconditionally part of a fulfilling life. John will have to come to a resolution of the religious and secular worlds. Wherever his thirst leads him and which call he eventually answers will constitute his future.

The sexual confusion in John's mind becomes apparent on the morning of his fourteenth birthday. While he was lying in bed wondering about the unusual silence of this Sunday morning, he stared at a yellow stain on the ceiling which "slowly transformed itself into a woman's nakedness" (17; italics mine). He then remembered that he had sinned, but we learn that "he had sinned with his hands a sin that was hard to forgive. In the school lavatory, alone, thinking of the boys, ...he had watched in himself a transformation of which he would never dare to speak" (17; italics mine). Baldwin displays within this very brief narrative time span the mind of John who almost simultaneously imagines a woman's body and then remembers his homosexual feelings.

John's memory mirrors the homosexual period through which every adolescent goes on his way to heterosexuality, according to Freud. An entrapment of the young man in this homosexual phase is the result of abnormal parental relationships, especially with the father, accordingly to this theory. Read in this manner, we witness that John undergoes the "normal" sexual development. Yet, the last line of the following paragraph, which states that "[John] would not be like his father" (18), suggests a rejection of the father and thus foreshadows John's homosexuality.

Even without a knowledge of Freud's theories, through opposing these images of boys and a woman in John's imagination, the author clearly demonstrates sexual 
ambivalence. So close is the identification between Baldwin and his character, he also seems to be hiding his own sexuality. Indeed, his vehicle John will never speak about his sexuality -- "[h]e was afraid to think of it" (16) -- because he saw Father James exercising his duty when he publicly warned Elisha and Ella Mae of the sins of the flesh, which are incompatible with the service to the Lord, and wished to advert that happening to himself. John is silenced through the doctrinal church, which is the author's tool to mention the issue of homosexuality obliquely, without the necessity of further discussing it since the story is told through the eyes of John.

Go Tell It On the Mountain in this sense then, also exhibits Baldwin's rebellion against the doctrinal church of his childhood, which did not permit any sexual expressions, apart from legally sanctioned sexuality. This is additionally revealed through placing John's attraction to the young saint Elisha within the walls of the church. Elisha who stirs these loving feelings in John and who is kind and caring toward John is the masculine role model John is longing for.

One of the complexities of Go Tell It On the Mountain, which characterizes all of Baldwin's novels, is that he always included autobiographical elements. Baldwin's difficult and almost hateful relationship with his stepfather, David Baldwin, left its traces in many of his essays and novels. This is why it is hard to determine whether Baldwin's depiction of disruptive parental relationships is merely a reproduction of the medicalized thinking about homosexuality or a reflection of his own life.

However, Baldwin was preoccupied with the oppressed situation of the AfroAmerican, and essays written prior to the publication of Go Tell It On the Mountain had 
established his firm reputation as a racial spokesman. He knew that the intolerance of the black community toward homosexuality could have easily undermined that position. This is why I think that his own problematic relationship with his father is certainly depicted in Go Tell It On the Mountain; yet I do not think that the chief motive for its implementation in the plot was to rework his past, but to affirm the causes of homosexuality as generally assumed, and thus avoid public censure.

This is why, in my opinion, Baldwin clearly concurs with societal theories about the causes of homosexuality. I derive this assumption from the Freudian elements in John's relation to his parents.

From his early childhood on John has developed an over attachment to his mother. Every time his mother was taken to hospital to give birth to his half-brother, Roy, and his two half-sisters, "folks said that [John] had cried and carried on the whole time his mother was away" (11). John's mother protects John against the wrath of his father, who did not keep his promise of loving John as if he were his own flesh and blood, and against the teasing of his siblings. She is also the only one who remembers John's birthday which makes John's "heart swollen with love for her" (29). Upon her remark that she is counting on John's becoming "a mighty fine man," John hopes that his mom would realize "the depth of his passion to please her" in his stammered "yes"(29). John, on the other hand, is the product of three fathers -- of his original father, Richard, who represents the weak and absent father, of his bullying stepfather, Gabriel Grimes, and God, the father, who as conceived by Christian fundamentalists represses John's sexual development. 
Richard, the biological father, took John's mother, Elizabeth, from the South to New York, but the conditions under which they lived separately in Harlem, without promised marriage, were not reassuring. Their happiness ends when Richard, falsely accused of robbery and put in prison, cuts his wrists after his dismissal because he could not live with the thought of having been beaten, shamed, and defeated. John inherited his intelligence and, as his mother observes, "a stiffness...that would be hard to break, but that, nevertheless, would one day surely be broken, as hers had been, and Richard's" (151).

John's stepfather, Gabriel, is a cruel and bitter black man who had come many years before from the South to Harlem in order to leave his sinful past behind and to be saved by the Lord. Through the 'sacrifice' of marrying Elizabeth with her illegitimate son John, Gabriel thinks that all his past sins were redeemed and that he was forgiven by the Lord. The relationship between John and Gabriel is mutually marked by hatred and contempt. Gabriel does not accept John as his son and John is aware of Gabriel's scorn. When John's brother, Roy, gets stabbed by a gang of black boys, John knows through the expression in his father's eyes that he loathes John "because John was not lying on the sofa where Roy laid" (38). He secretly wishes at this moment that Roy, "to bring his father low, would die" (39). So great is John's hatred for his father that he wishes that his father would die!... Yet in the very grave he would hate him....The grave was not enough for punishment, for justice, for revenge. Hell, everlasting, unceasing, perpetual, unquenched forever, should be his father's portion. (126; Baldwin's italics) 
Gabriel deeply hurts John in calling him ugly and "buck-eyed" (41) and in this way is successful in establishing in John the negativity of the self which, according to Bergman, is a signifier of the discourse of homosexual experience. John indeed is tormented by the thought of being ugly (25) and he dreams of becoming rich, successful, and wearing fine clothes, unlike his father. Gabriel's hatred toward John and his constant mocking of John's "big buckeyes" (41) have, I would suggest, also another cause. John's big "staring eyes" make Gabriel afraid, because they have stared "into the bottom of Gabriel's soul"(130) right from the first encounter between the Baby John and Gabriel. These eyes, which remind Gabriel of all the sins he wants to forget and bury in the past make Gabriel feel uncomfortable, and unable to face the truth and take responsibility for his sins, he pours all his anger on the stepson, John. Thus, eyes, which are a crucial means for establishing any kind of relationship project erotic energy from others onto John, who is still the observer and passive recipient.

Gabriel's mocking of John's eyes is drawn from Baldwin's own life. His stepfather frequently commented on Baldwin's ugliness, which made Baldwin believe that his race is ugly. This and other events in Baldwin's life led him to a self-deprecation of his body that made it difficult for him to associate sexual contacts with others with love or beauty. All these happenings scared the young Baldwin so much that he, as he remembers in Leeming's biography, "found the Lord" for protection and "safety from himself, who at the age of fourteen had become, he feared, 'one of the most depraved people on Earth"" (24). 
Thus, we are faced with a loveless father - son relationship in the novel, which is a reflection of the author's childhood and his problematic relation to his stepfather, but which also fits into the dominant medical explanation for homosexuality in the postwar era.

Another indicator of homosexuality represented in Go Tell It On the Mountain is the "unlikeness" of the homosexual child within the family as described by Bergman. Bergman testifies that the son who will be gay learns early that how he is perceived differs sharply from how he perceives himself and in this way adds to forming his sense of otherness (36). John's sense of otherness arises from the fact that John is robbed of the "conscious feeling of having a personal identity" which is constituted, according to Erik Erikson, by one's perception of selfsameness and that others recognize one's sameness (qtd. in Bergman. Gaiety Transfigured: 36)

John tries to find a sense of himself amidst what other people have said about him. Thus, for example, he looks at his face in the mirror as a stranger might do, a face which according to his father "was the face of Satan" (25). He desperately seeks to discover what other people see. "But he saw only details...and he could not tell what he most passionately desired to know: whether his face was ugly or not" (25). ${ }^{9}$ Confused and insecure about his outer appearance, John, on the other hand, is very much aware of his inner strength -- his intelligence. When he was five years old and in the first grade, the school principle showed appreciation for John's brightness. John began to perceive his individual existence at that moment because "he was noticed by an eye altogether alien and impersonal" (18). John felt that this moment gave him a weapon. He 
understood that he had in himself a power that other people lacked. His intelligence "was his identity, and part...to which he clung in order to withstand his father" (19). And it also meant a little consolation for him. He wanted to be one of the boys who played in the streets, "unfrightened, moving with such grace and power, but he knew this could not be. Yet, if he could not play their games, he could do something they could not do; he was able...to think" (28).

Thus, we learn that John is in the period of forming an own identity, but yet his sense of the self is not strong enough. His scattered ego has resulted from a rejection of his peers, the children playing in the streets. Furthermore, his father distinguishes between him and his other son, John's half-brother, Roy. The father constantly mocks, scolds, or simply neglects John, whom he just thinks of as "the son of the bond-woman" (99), whereas he puts Roy on a pedestal and feels a deep love for him. Thus, "he muttered sweet, delirious things to Roy" when he laid bleeding on the sofa after the stabbing, and John noticed his "different voice, so sad and tender" (39; italics mine)!

Moreover, John has his entire life been reminded of his difference in comparison to his brother and his sisters through the photographs of the Grimes' children, exhibited in their house. John was not dressed like his brother and his two sisters in the picture but "lay naked on a white counterpane, and people laughed and said that it was cunning" (26). John felt "shame and anger" at being exposed to visitors, which led everybody to the conclusion that he was a "funny" child (26). John's response to the photograph and reception recalls the crisis through which a gay child goes, resulting from other people's views and expectations of him versus the views and expectations he has of himself. In 
this way, John discovers from his environment -- his father, his peers, and the photograph viewers -- that the others instead of recognizing a sameness perceive John's otherness, and thus add to his sense of feeling different. He is ultimately stamped by his father as the "fool of the family" (34).

Claude J. Summers in Gay Fictions furthermore argues that, according to the contemporary social and sexual ideology in the 1950s, children who were products of a broken home were expected to be neurotic (235). Baldwin seems to have affirmed this prevalent assumption. Consequently, John, the bastard child, is "funny" (26) in the visitors' eyes, which symbolize the views of society.

Bergman explains in the line of Freudian thought that male children who will become homosexual have strong feelings -- good or bad -- toward their fathers, but rarely identify with them nor with their mothers, ${ }^{10}$ and concludes that their sense of otherness seems to reflect alienation from both parents. It is typical, though, Bergman adds, that a gay child is repeatedly encouraged to admire and emulate the father, and what the son cannot be, he wishes to love and be loved by. His failed identification leads to attributing additional desireableness to the father (36).

This pattern is clearly discernible in Go Tell It On the Mountain. John's religious upbringing leads to his consciousness of having been overtaken by sin, and he assumes that he can only be equal to his father and be able to look into his eyes, if he is saved. For he had "looked, as the accused son of Noah had looked, on his father's hideous nakedness" (170). "This, and not that other, having looked on his father's nakedness and mocked and cursed him in his heart" (170; 
italics mine) make John, who considers himself "the lowest among these lowly," (174) feel that he has to be saved and be forgiven in his sin to deserve his father's love and be an equal to him. He undergoes the conversion experience in a last desperate effort to gain his father's love and the first words he utters are "Father! Father!" (172; Baldwin's italics). However, conversion results in an even greater rejection by his father. Feeling unloved, alone, and misunderstood by his family, John turns to Elisha as the only alternative. "[T]hey did not know what he was looking for, they could not help him search. He wanted to find Elisha, who knew perhaps, who would help him" (173).

Elisha can be a substitution for the hard father. In contrast to his father who would have an angry fit, if John was not able to answer a question, "Elisha would smile and reprimand him gently" (13), showing the love and care John so much longed for from his father. That is why John decides that he would have a life different from his father's.

In church John is fascinated and distracted by Elisha, not merely because Elisha is only seventeen but already saved and a preacher. "John stared at Elisha all during the lesson, admiring the timbre of Elisha's voice, much deeper and manlier than his own, admiring the leanness, and grace, and strength, and darkness...." (13) And when Elisha paused to ask John a question he reacted like somebody in love for the first time, but aware of the inappropriateness of his thoughts: "John was ashamed and confused, feeling the palms of his hands become wet and his heart pound like a hammer" (13). John knows that his thoughts in the church regarding Elisha are not permissible, and when Father James speaks of the sin he had uncovered in the church, "John felt himself grow dizzy in 
his seat and could not look at Elisha where he stood" (15). This passage could be read in a twofold sense, implying homosexual tension arising from John's sexual attraction to Elisha, but simultaneously displaying a tormented author's mind because Baldwin is aware of the impropriety of these emotions.

The air around Elisha as he is seen through the narrative voice of John is charged with erotic energy. For instance, the wrestling that takes place between John and Elisha on the church floor carries a sexual connotation. According to James Giles, men wrestling has often been used by writers as "a significant device for underscoring covert homosexual attraction" (369). The text affirms this because after the wrestling John "stared in a dull paralysis of terror at Elisha's body....He looked into Elisha's face, full of questions he would never ask" (48). Yet, John feels obliged to be silent about his sexual thoughts under the roof of the church. Even Elisha's piano play in the church is laden with sexual tension, which seems to become ecstatic, close to an orgasmic experience by the way John views him:

...the muscles leaping and swelling in his long, dark neck....It seemed that he could not breathe, that his body could not contain this passion,....his sweat loosening the grease that slicked down his hair; and the rhythm of all the others quickened to match Elisha's rhythm; his thighs moved terribly against the cloth of his suit...and all his body dancing as though it would never stop...until he dropped like some animal felled by a hammer - moaning, on his face. (15; italics mine). 
Although John, in Ge Tell It On the Mountain, is finally pronounced by the saints to be saved and to have reached salvation, I think it is eventually another kind of salvation James Baldwin wants to propose because after John awakens "a sweetness filled" (176) him at the sound of Elisha's voice. As he moves among the saints "something [begins] to knock in that listening, astonished, newborn, and fragile heart of his; something recalling the terrors of the night, which were not finished, his heart seemed to say; which, in this company were now to begin" (178). Thus, when John leaves the church on the morning after the salvation night he finds himself in a deep conflict between his feelings and the precepts of his church. He begins to sense the sexual roots of the terrifying release he had experienced on the church floor as the saints had labored over him.

John's "second birth" endows him with the power to stand up to his stepfather and to confront him. Upon their return to his father's house, John feels afraid because "he must leave Elisha, step out from under his protecting arm, and walk alone into the house - alone with his mother and his father. And he was afraid. He wanted to stop and turn to Elisha, and tell him ... something for which he found no words" (189). This something, James Baldwin himself is not ready to express yet, and this is why he left these three boldly printed dots indicating the impermissible and thus unpronounceable feelings. "John, staring at Elisha, struggled to tell him something more - struggled to say - all that could never be said." (190; Baldwin's italics). Elisha does not understand John and eventually leaves him. However, 
John, unlike his father, swears to never forget his past, his feelings, and his sins, and he will go on in his life. He begins to suspect that real salvation would come from accepting rather than from running away from life. This elevates him because he will move away from the sham of the church. " James Baldwin expresses this in a very artistic and symbolic way: "John moved up to the short, stone step, smiling a little, looking down on them" (191; italics mine).

Gabriel, John's stepfather, did not kiss John after his night on the floor, whereas he had kissed Elisha after Elisha's communion. It is Elisha who "kisse[s] John on the forehead, a holy kiss" (191). And this kiss is "like a seal ineffaceable forever," it will determine John's future because John will start a new life trying to fulfill his desire for a meaningful human contact. In this way, his "conversion" frees him from his father's authoritarian control by replacing them, the earthly and the heavenly father, with another more supportive male presence. John had tried to be saved, to win his father's love, and he begs Elisha "please remember - I was saved. I was there"(191; Baldwin's italics). But his father does "not smile"; moreover, he rejects him and so John, at the beginning of a new morning and life, feeling the March wind indicating the rise of spring and love, is ready. He finally answers the call of the "Spirit" and the "bride" to "take the water of life freely" (9). This is why he says at the end of the novel: "I'm coming. I'm on my way" (191).

The ending of Go Tell It On the Mountain exhibits two things: The unwillingness of Baldwin to directly name homosexuality, although he desires to 
do so, which is the reason for his employing symbols to highlight the unspoken; and secondly the message between the lines that John will become a homosexual because he does not identify with his father and his father's house and is going to leave it behind him, recognizing his homoerotic needs after his conversion.

Emmanuel S. Nelson suggests that through the blending of the erotic and the spiritual and the presenting of homosexual attractions in religious surroundings, Baldwin dedicates himself to homosexuality and mocks the religion of his childhood. As Leeming appropriately summarizes this stormy period of Baldwin's life that found expression in Go Tell It On the Mountain: "The wider possibilities of the arts and the flesh had won out over the narrowness of the church" (31).

In contrast to Nelson, I think, though, that the ending of Go Tell It On the Mountain does not necessarily imply Baldwin's dedication to homosexuality. Through the character of John, James Baldwin reveals his own doubts, fears, and anxieties that accompany the awakening and growth of John's homosexual awareness. The use of ironic voices during the conversion scene makes the meaning of John's salvation ambiguous. In this manner Baldwin distances himself from the text and leaves it for the reader to interpret it in one of several ways. This is why, symbolically speaking, James Baldwin is in my view at this point still struggling to publicly come-out as a homosexual writer, based on the anxieties he expressed in the Gide essay. Yet, Baldwin wanted to tell his audience that he is on his way to coming-out, with his last sentence. 
Most importantly, this book reveals the author's yearning for love and genuine human involvement, which can only come from an acceptance of life and love which, as he once said, "sometimes comes in strange packages". This, as in the case of Go Tell It On the Mountain, might mean a necessary divorce from the Christian church, which he explains ten years after the publication of his first novel: "If the concept of God has any validity or any use, it can only be to make us larger, freer, and more loving. If God cannot do this, then it is time we got rid of him." (The Fire Next Time 30). 


\section{CHAPTER III}

\section{THE BRIDGE TO GIOVANNI'S ROOM}

In comparing Go Tell It On the Mountain and Giovanni's Room it seems very interesting to me to notice Baldwin's various moves. Go Tell It On the Mountain deals exclusively with Afro-Americans in the very limited setting of the home and the storefront church in Harlem, and the protagonist is very young. The novel focuses primarily on issues concerned with the history and life of Afro-Americans in Harlem. Homosexuality is only an underlying theme in the novel.

In Giovanni's Room the action is located in Europe, the so called Old World, and more specifically, in France. The heroes are all Caucasians and the setting is mainly in gay bars and Giovanni's room. The first person narrator is older than John in Go Tell It On the Mountain, indicating that he should be fully aware of his sexual desires, in contrast to the sexual confusion that is usual in the teenage period in which homosexuality, according to Sigmund Freud, is "normally" a temporary and transitional stage.

From these opposing features of the two novels I deduce that in Giovanni's Room Baldwin wanted to distance himself completely from the American scene and the issue of race and deal with homosexuality as a separate issue. He was preparing to challenge the artificiality of constructs like masculinity, sexuality, and race which he accomplishes in 
his subsequent novels. However, I would argue, to successfully combine black and white, straight and gay, he had to work his way up to that point and deal with these issues separately in order to position himself and bring his audience to the point where it could handle both subject matters combined. Moreover, Baldwin had always resisted being considered a writer who only writes for a certain audience -- whether exclusively black or homosexual. He told Richard Goldstein in 1984 that when he turned Giovanni's Room in, his publisher, Alfred Knopf, refused to publish the book as a favor to Baldwin. Baldwin was told to bear in mind that he was a young Negro writer with a certain audience, and he was not supposed to alienate that audience. Baldwin subsequently went to England and published it there (177).

Stephen Adams in his book, The Homosexual as Hero in Contemporary Fiction, develops an interesting idea in his comparison of Go Tell It On the Mountain and Giovanni's Room. He considers both novels as an exploration of the extent to which inner drives can be contained within available, approved models of identity. John Grimes attempts to express his socially unacceptable thoughts within the sanctuary of the church. David in Giovanni's Room seeks refuge in conventional, outward trappings of manhood in a vain attempt to kill his homosexual longings. Both protagonists utilize mechanisms of self-betrayal and sacrifice personal fulfillment in an attempt to fit into the scheme of conformism (Adams 37). ${ }^{12}$

Moreover, Baldwin was very courageous in writing a homosexual novel during the homophobic era of the Cold War years and the period of violent racism which culminated in the Civil Rights Movement in the 1960s. By then he had already gained a 
wide national and international reputation as a racial spokesman for the Afro-Americans. Throughout his entire life he saw the need to fight against the oppression of the AfroAmerican, which he did in his many essays and speeches. Yet, especially during the Civil Rights period, many people wanted to see action and militancy, and I assume that Baldwin as a homosexual could easily undermine his power as a fighter for racial equality for both, blacks and whites, because of his so called effeminacy. This is why, I suppose, not merely for the purpose of entertaining and educating a homosexual as well as a heterosexual audience, but also in order to protect himself to be able to fulfill his mission both as a racial spokesman and as a writer, Baldwin hesitantly invoked homosexuality in his first novel, Go Tell It On the Mountain, or cast a tragic light upon it in Giovanni's Room. Emmanuel Nelson displays a similar opinion in his article, "The Novels of James Baldwin." He says that the publication of a novel like Giovanni's Room that handled with dignity and romantic intensity the sexual love between men in the critical sociopolitical climate of America in the mid-fifties was a single act of "personal and literary rebellion" (13). By publishing this novel, Nelson explains, Baldwin "risked his professional reputation and the very real possibilities of alienating a substantial segment of his growing white audience and antagonizing a large number of blacks" (13). In an interview given many years later, James Baldwin explained why he had to publish Giovanni's Reom, though: "[It] comes out of something which tormented and frightened me, the question of my own sexuality. It meant that I had no secrets, nobody could blackmail me; you know, you didn't tell me, I told you" (video: The Price of the Ticket). 
An additional constraint on Baldwin was his close bond to his family, whom he did not want to hurt, embarrass, or disappoint. However, always very critical about the American society, Baldwin felt that he had to write Giovanni's Room. David Leeming, who is Baldwin's most recent biographer, says that Baldwin tried to explicate to his mother the reality of a writer's mission. In a letter to her he explains that he was born to translate the painful human experience into art (qtd. in Leeming: 115). Thus, in being honest about himself and by displaying his anguish and loneliness through his fictional characters, he created the means which allowed him to carry his criticism of American society into his fiction. Homosexuals were in Baldwin's opinion just the latest example of America's apparent need to repress differences in the name of morality. In a speech on the topic, "Race, Racism, and the Gay Community" (1982), he said that he considers gays as just one more group of prisoners in a society that was not aware that it was itself an emotional and spiritual prison (qtd. in Leeming: 359). He displayed this insight almost thirty years earlier in Giovanni's Room through the character of Giovanni who says to David, the typical average American: "You love your purity...You want to be clean...You want to despise Giovanni because he is not afraid of the stink of love. You want to kill him in the name of all your lying little moralities...you are immoral" (187; Baldwin's italics). 


\section{Giovanni's Room}

James Baldwin said in an 1984 interview he gave to Richard Goldstein about the United States that he saw nothing in American life to aspire to: "It's all so very false. So shallow, so plastic, so morally and ethically corrupt" (205). These are precisely the problems he tackles in Giovanni's Room. Through Giovanni's Room James Baldwin wanted to convey something about the American loneliness growing out of the urge to be accepted in this society. The American protagonist, David, in his battle to conform to American mores, through a constant self-denial and also betrayal of his environment in order to not be an outcast, comes to face loneliness because he loses in this process parental love, friends, and lovers. Moreover, as Claude J. Summers says, Giovanni's Room tackles the inability of Americans to face facts and express emotions. For that Baldwin needed to use the most ordinary type of American as a protagonist -- the white American Protestant. Baldwin describes this novel himself as short and tragic; an American boy finds something and loses it, and in the acceptance of the loss the protagonist takes on heroic dimensions for the author.

The novel opens with the young, blond American, David, standing at a window in a house in Southern France. On this "most terrible morning of [his] life" (7) he contemplates, in a series of flashbacks, the events which eventually led to the execution of his Italian lover, Giovanni, on that morning. David grew up with his father and his father's sister, aunt Ellen, after his mother's death when he was five. His father drank a 
lot and was proud of being a 'stud' in that he had many affairs with women and wanted David to become like him. He and his sister had many fights over the question of David's up-bringing. David had a best friend, Joey, in his teenage years; however, their friendship was ended by David after they had a sexual encounter. David leaves America as a young man in order to escape his past and to find out about himself. In Paris, he intentionally moves in homosexual circles just to prove to himself that he does not belong there. Through Jacques, an old rich homosexual who likes David and often takes care of his expenses, hoping that this relation might lead to something more, David is introduced to the new barman, Giovanni. David and Giovanni immediately detect their mutual attraction and a relationship develops between them.

Giovanni is Italian and had just shortly before David's arrival in Paris started to work in Guillaume's bar. He had been married and lived as a farmer in an Italian village. After his wife gave birth to a dead baby, Giovanni cursed his religion and turned his back on his village to live in Paris. Very desperate, he is filled with new hope for a happy life at David's appearance.

David never told Giovanni that he has an American girlfriend, Hella Lincoln, who went to Spain for a while to think over her relationship to David. When she returns to Paris, Hella and David decide to marry and David leaves Giovanni. This decision destroys Giovanni who soon afterwards also loses his job at Guillaume's bar because of a trivial incidence. Guillaume, although he promises to give Giovanni his job back if he has sex with him, does not keep his word but threatens to humiliate Giovanni in telling everybody about it. Giovanni in his anger and humiliation kills Guillaume and is soon 
after caught and sentenced to death. When Hella finds out about David's homosexuality, she breaks the engagement and flees to America.

In my attempt to adhere to the two stages of the coming-out process as distinguished by Diana Fuss, Giovanni's Room reflects in my view still the first part of this process: the individual, trying to accept his homosexuality, before he has learned how to integrate his sexuality in his life. This process, in comparison to Baldwin's first novel, Go Tell It On the Mountain, is articulated in a much more frank manner, including an accurate and unsensationalized portrayal of gay subcultures and a detailed account of the coming-out experience. It mirrors a recognition of the profound effects of stigmatization on the individual. As Baldwin tries to show, the difficulties of the comingout process have much less to do with the acceptance of homosexual desire than with adjusting to the social stigma attached to it. In this way, Baldwin fulfilled his promise of being "on my way" which ended the first novel, Go Tell It On the Mountain; his decision to deal frankly with homosexuality proves his willingness to face honestly his own "sexual dilemma." Yet, the principally negative ending of Giovanni's Room implies to me that he has not yet come to a healing acceptance of homosexuality in his fiction; he is not yet ready to envision the legitimacy of a homosexual relationship. Moreover, although Baldwin exhibits in Giovanni's Room his belief in the genuineness of homosexuality, he displays again his agreement with the dominant medical Freudian explanation of homosexuality with regard to the parent - son relationship.

It seems to me that Baldwin tries to explain David's homosexuality as the outcome of an abnormal parental relationship. First, he adheres to the belief in 
domineering mothers. David lost his mother when he was five. His father and his father's sister, aunt Ellen, eventually raise David, but they were constantly fighting in this house in which his mother's photograph on the mantelpiece "proved how her spirit dominated the air and controlled us all" (18; italics mine). He continued to have nightmares about her death about which he said that they "had this unsettling effect on my imagination" (17), hinting in its ambivalence that it could be taken as an explanation for David's subsequently 'abnormal' development.

Bryan Washington also argues along these lines in The Politics of Exile, yet extends his illustration to all females and not just the mother figure. He explains that David as a misogynist represents the 1950's ideological cliché that men who desire men - whether repressed or sexually self-aware -- despise women. David's sexual 'problems' can be traced back to childhood. He remembers his dead mother as "blind with worms, her hair as dry as metal and brittle as a twig, straining to press me against her body; that body so putrescent, so sickening soft, that it opened...into a breach so enormous as to swallow me alive" (17). Washington evaluates "this parodic Freudian moment" (77) as an example of how Baldwin acknowledges the at that time popular theory that homosexuals either loved their mothers too much, or in their inability to be like their mothers, grew to loathe them and, consequently, all women. In corroboration, he cites the description of Aunt Ellen as "always overdressed, overmade-up,...and with too much jewelry everywhere, clanging and banging in the light" (19). The American girl, Sue, ${ }^{13}$ as another example, looks for David "like a broken-down movie queen facing the cruel 
cameras again after a long eclipse" (131), her smile "as rigid as the skeleton beneath her flabby body" (135).

I think it would also be interesting to draw an analogy between America, the mother country, and its homosexual sons, with David as the exemplar. Baldwin powerfully conveys that David's anxieties are not simply born out of his fear of being an outcast within the heterosexual majority, but are fed by his own witnessing of "a fairy who was later court-martialed out" (31) of the Army. David's feelings and indecisiveness are thus very strongly informed by his dominating mother country where, as he tells Giovanni, homosexuality “is a crime...I grew up there" (107; Baldwin's italics).

David's father, on the other hand, is the weak and absent father whose attention David so desperately longed for as a child (18). David's father, who is the only one who has some authority over David, is often drunk. He instills in his son the idea about the linkage between manliness and sexual performance, not wanting his son to become "a Sunday school teacher" (24), which makes David despise him from that time on; yet, David admits that he does not know why. I think the notion is underlying that David can not and will never be able to identify with his father in the sexual realm or become a "man" in the way his father defines a man. Not able to aspire to his father's ideals, the adolescent homosexual David rejects his father and "has always since then been in full flight from him" (25). The author's belief that a problematic father-son relationship triggers the homosexuality of the growing-up child is also underscored through David's first person narrative voice, explaining his father's inability to comprehend the difficuities of their connection "because he would then have had to face the knowledge that he had 
left something, somewhere, undone, something of the utmost importance" (25). In this way, the developing child's sexual orientation is placed into the father's hand who, if he is a weakling ${ }^{14}$ in the Freudian view because he does not have any authority over David, has to be blamed for his son's abnormality.

Moreover, Giovanni's Room exposes us to the problematic issue of the family and the general perception of the homosexual as a threat to it. Through the uncertain, torn, and guilty character of the protagonist, David, but also through Giovanni, James Baldwin displays the most anti-homosexual prejudice that gay society is irreconcilable with "family life." Anita Bryant in her subtitled autobiography, The Survival of Our Nation's Families and the Threat of Militant Homosexuality (1977), rigidly declares that "male and female are programmed to mate with the opposite sex. This is the story of two and a half billion years of civilization, and any society that hopes to survive will have to recognize this." This is why, in her opinion, homosexuality militates against the family. The choice of the homosexual is dire, according to her. He might choose between a lover "and with him chaos, anarchy, the end of civilization, or raising a family and preserving the universe from destruction" (qtd. in Bergman. Gaiety Transfigured: 188). In my opinion, Baldwin displayed the same belief almost twenty years earlier in Giovanni's Room.

Baldwin's perception of the incongruity between a domestic life and a homosexual relationship is reflected in the novel twice. First we learn that Giovanni had a "normal" life with a loving wife in a little Italian village, and he recounts that he "was not unhappy then and [he] was not lonely" (183). However, after their baby was born 
dead, "gray and twisted" (185), Giovanni left everything behind and came to Paris. $\mathrm{He}$ considers Paris as God's punishment for "all [his] sins and for spitting on His holy son" (185), and he is sure that he will die there. I assume that Giovanni as Italian is Catholic, and the Catholic church did not sanction homosexuality. Giovanni attempted to obey the religious rules; yet he loses his faith in God after the tragic happenings. However, it is important to notice that Giovanni, as Italian/ European, once he had freed himself from his religious bonds is less repressed because his Mediterranean temperament with its frankness, warmth, and uninhibited desires takes over. Giovanni is the representative of the Italians who are supposed to be "too fluid, too volatile, [and to] have no sense of measure" (50). This is why he sees David's arrival in Paris as a motivation to continue with his life because his temperament does not make him, as he says, like "other people [who] measure all the things before they permit themselves any act whatever" (51). Again, I think, Baldwin adapted to societal assumptions by showing the destruction of Giovanni's family. Baldwin wanted to suggest that the still-born baby was a punishment because Giovanni, despite his homosexuality, attempted to lead a "normal" family life, but as perceived by church and society, must bring about the destruction of the family as a homosexual. The baby's death is an affirmation that who he is and what he does goes against nature. Bryan Washington suggests, on the other hand, that the still-born baby indicates Giovanni's successful progression because he was able to throw off the yoke of convention and move on (78). Yet, I think this progression took place only forcibly and would not have happened but for the child-death. Forced to recognize that homosexuals cannot have a conventional family life, Giovanni finally follows his predetermined way. 
David faces the same problem. While walking nightly through the streets of Paris he recalls that he "wanted children...wanted to be inside again, with the light and safety, with my manhood unquestioned, watching my woman put my children to bed" (137). Yet, he feels that instead of achieving this web of safety, he had only come to Paris to be destroyed and with him all his dreams of a family. In this way, Giovanni's Room does not give any hope for homosexual family units.

However, I fully agree with Alan Sinfield's statement in Cultural Politics - Queer

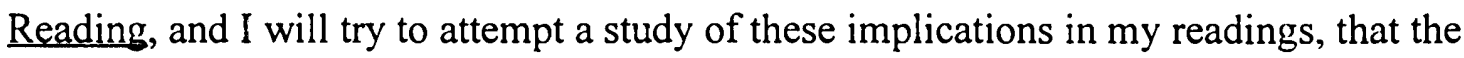
goal of literary analysis is not to track down gay characters, but to see what intramale sex enabled and disabled. Sinfield stresses that the importance does not lie in who did what with whom, but what was perceived as being done, and the anxieties that informed such perceptions (19).

An affirmation of Sinfield's argument can be found in the character of Jacques who is like a mentor to David in Giovanni's Room. He is an old homosexual, representing the epitome of the fate of one who tried to deny his sexual self, and he informs David about the importance of these perceptions. Jacques warns him that depending on David's own state of mind, the "five minutes in the dark" can be "dirty because you will be giving nothing, you will be despising your flesh and his. But you can make your time together anything but dirty; you can give each other something which will make both of you better - forever - if you will not be ashamed, if you will only not play it safe" (77; Baldwin's italics). If Jacques' life is shameful, then it is partly because of those who like David are too ashamed to love. For it is only love that matters and 
nothing else, says Jacques, in this way demonstrating the message of all of Baldwin's fiction.

David has from the beginning of his sexual awakening been in a constant battle between his sentiments and his deeds. One example is the first sexual act with a male in David's life, which occurs during his adolescence. David and his teenage friend, Joey, grew very fond of each other during one summer and during an idyllic weekend spent on the beach, they had sex at Joey's house. We are told through the narrative voice of David that he felt intense joy thinking "that a lifetime would not be long enough for me to act with Joey the act of love" (14). However, David awakens the next morning painfully aware that he has to end this friendship. But he does not tell Joey about his cowardly decision, knowing that the slightest protest on his friend's part would weaken him and overthrow his resolution. In this manner the reader is informed about the genuineness of David's feeling; yet, "It was borne in on [him]: But Joey is a boy" (15; Baldwin's italics). All that he has heard about homosexuality, "black, full of rumor, suggestion of half-heard, half-forgotten, half-understood stories, full of dirty words" (15), determines David's terror, shame, and fear that he will lose his manhood, a reflection of how he had internalized society's views of homosexual love.

Moreover, Baldwin sharpens the contrast between personal emotions and social moral 'prescriptions' through the presentation of the genuineness of homosexual desire. Baldwin manages this in a skillfully artistic manner, agreeing with what Bergman writes about the nature of the sexual experience for gay men. Thus, while Baldwin depicts the night with Joey in a very emotional and erotic style, the reader is told of the "mechanical 
responsibility" David felt in making love to Hella (9) or his revulsion during the "grisly act of love" (133) with Sue, which brought him to the consciousness that what he had been afraid of "had nothing to do with [his] body" (133). He is able to sexually perform with either gender, but real satisfaction is only provided to him by men.

Giovanni's Room repeatedly reflects the sense of otherness and alienation which is characteristic of male homosexual discourse as described by David Bergman. Thus, the placing of the novel in France in itself suggests alienation from the American scene. This removal is closely related to Baldwin's years, spent as an expatriate, in particular, in France and Turkey searching for his identity. This is also the reason his protagonist decides to leave for France: "[A]s we say in America, I wanted to find myself" (31). With this move, in my opinion, Baldwin wanted to demonstrate that the rigid American social mores did not leave sufficient space for people to break free from the boundaries of social acceptance in the process of recognizing their identity.

James Baldwin was familiar with Sigmund Freud and the willful and easy reception of his psychoanalytic theories in America. ${ }^{15}$ This is why I think he could not situate a novel such as Giovanni's Room in America and gain the same effect or convey the same message at a time when psychoanalysis was so popular. The French setting allowed him to create believable characters who protested against the so-called plasticity of the soul and the tendency to conformism and also gave him the room to criticize America and thus the means to "call society into question." His American protagonist was faced with an environment more outgoing and self-affirming than himself; an environment which was able to challenge his avoidance of self-questioning that was the 
logical consequence of the principle of conformity. Through his clever technique of removing the plot from the American scene, Baldwin found it possible to draw a believable, detailed account of the coming-out experience because it did not happen in the tight American surrounding but in France, which has been built upon the sophisticated culture, history, and traditions which endow the French with a much keener sense of stability and security. A direct affirmation for this line of reasoning can be found in a dialogue in the text between Giovanni and David:

'The ocean is very wide,' [David] said. 'We have led different lives than you; things have happened to us there which have never happened here. Surely you can understand that this would make us a different people?' 'Ah! If it had only made you a different people!' [Giovanni] laughed. 'But it seems to have turned you into another species. You are not, are you, on another planet? For I suppose that would explain everything.'

Stephen Adams in his analysis of Giovanni's Room discovered another interesting connection for the placement of the setting in France. Baldwin observed in his essay, "A Question of Identity" (1954), that many young Americans who were drawn to the bohemian life in Paris, soon after losing their heads and morais and having love affairs began "to long for the prison of home - home then becoming the place where questions are not asked "( The Price of the Ticket 95). Adams argues that David fits into this pattern, attempting to preserve his 'innocence' at all costs, a quality Baldwin associates 
specifically with white Americans. Adams found proof for that in Baldwin's essay "The Black Boy looks at the White Boy" (1961) in which he argues:

The things that most white people imagine they can salvage from the storm of life is really, in sum, their innocence....I am afraid that most of the white people I have ever known impressed me as being in the grip of a weird nostalgia, dreaming of a vanished state of security and order. (The Price of the Ticket 294)

Thus, Adams considers David's step of going to Paris "to find himself" as a means to discover an assurance of his innocence (38). Adams says that David flirts with the gay underworld to persuade himself that his 'home' is not there. The attempt, however, fails when he meets and falls in love with Giovanni.

Most interestingly, Baldwin, who considered Henry James as one of his spiritual fathers, employed in Giovanni's Room the genre which was perfected by Henry James, where the American innocent was put to the test of experience in the Old World (Adams 38). Indeed, Guillaume, the bar owner, tells Giovanni that David is "just an American boy, after all, doing things in France which [he] would not dare to do at home" (142). When Hella's and David's bohemian lifestyle raises "threatening" questions with regard to conventional man- and womanhood, Adams explains, they both wanted to seek refuge in conventions, looking backwards to America to restore some sense of order and security in their lives. This is the reason, David admits, that he asked Hella to marry him. Remembering the "peculiar innocence and confidence" (9) of their nights, he wanted to "give [himself] something to be moored to" (10) because "nothing is more unbearable, once one has it, than freedom" (10). 
Mark Lilly in Lesbian and Gay Writing speaks of gayness as a lived experience of alienated desire. More precisely, he defines alienation as the loss of identity with one's deepest thoughts, feelings, and needs; as the loss of meaning; the psychological divorce from one's essential sexual nature; and lastly, powerlessness resulting from social categories which order, confine, and discipline human beings (129). One powerful passage which exhibits the characteristics as described by Lilly takes place in the novel before David comes to the decision to leave America. David admits that he has become a "specialist in self-deception" by deciding "to allow no room in the universe for something which shamed and frightened me" (30). Upon his arrival in Paris, David continues this process of "self-deception" by intentionally moving in le milieu, anxious to prove that he was not one of them "by being in their company a great deal and manifesting toward all of them a tolerance which placed [him]...above suspicion" (33). This alienation is David's response to a homophobic society which estimates individuals' worth according to class, race, gender, and sexuality, but which leads to his and his lover's doom because successful relationships can not be lived out under such restrictive conditions, in Baldwin's opinion.

I consider alcohol as a tool in James Baldwin's novels that serves to loosen these restrictive conditions by putting the characters' minds at ease under its influence and thus making actions possible because of a provisional liberation of the spirit. Apart from Go Tell It On the Mountain one can observe that bars and alcohol play consistently an important role in Baldwin's fiction. Throughout the entire plot of Giovanni's Room there is a great deal of drinking noticeable. Bryan R. Washington in The Politics of Exile 
explains that the highly visible abuse of alcohol implies a self-loathing and suggests a controlling need to numb the senses and the mind (130). This becomes visible throughout the novel where alcohol is involved in almost every conversation and precedes every sexual act. It is for David, the distressed protagonist, a means to overcome his anxiety or discomfort and thus he often "felt that [he] had better get drunk" (57). The alcohol also prompts him to unconsciously reveal his true sexual orientation. One example is that he was seen flirting with a soldier in a bar in his drunkenness, although he later denies it.

Lilly explains that gay writers often created handsome characters as another means to accommodate the process of initiating or simply justifying a male - male relationship because if the protagonists were average-looking the problem of whether or not they had likable personalities would hinder the flow of fantasy (Lesbian and Gay Writing 173). Baldwin conforms to that scheme by constructing a physically very attractive and well-built, "insolent and dark and leonine" Giovanni who immediately allures David, and David himself is also very handsome, as the reader is informed. The immediate mutual attraction between David and Giovanni is thus above all a result of their physicality and eases the beginning of a relationship, which David, in particular, in his tortured and uncertain state of mind, would otherwise surely not have started. Consistently throughout the text the reader is informed that David truly desired Giovanni, that he wanted to stay forever with him in that room, and that "[he does] not think that [he] will ever love anyone like that again" (148). Giovanni is presented as the living example that homosexuality is not in itself "dirty". Giovanni's pride and joy, the 
genuineness of his feelings, are written on his face when he introduces David to a friend; "Something is burning in his eyes and it lights up all his face" (71). His happiness about his friendship with David influences his whole appearance, and the "insolent, dark, leonine" Giovanni David had seen first in the bar had turned into his "baby [who] came indeed, through all that sunlight, his face flushed and his hair flying, his eyes, unbelievably, like morning stars" (79).

And yet, because of David's consistent self-deception and denial, the novel has an unhappy ending for all the main characters: Giovanni is executed at the end after killing the bar owner Guillaume; Hella flees in shock to America; and David is left alone in his anguish and despair. David has from the beginning been depicted as the tormented figure who "had been playing a deadly game" (58), and although he tried to win by cheating, he is the loser on a first evaluation because he has long lost his father, he lost his best friend, Joey, his fiancé, Hella, and his lover, Giovanni. Herein, I think, lies the key to Baldwin's estimation that Giovanni's Room is "tragic." David's internal sexual struggle is primarily characterized by an intensely individualistic search for a personal identity within the larger heterosexual and homophobic community. Opposing emotions, such as he "was utterly, hopelessly, horribly glad" (58) at Giovanni's sight or his desire to "be locked in that room forever with [Giovanni]" at the moment he tells Giovanni that he must leave him, signify his tormented state of mind with regard to what he wants to do yet does not dare to commit himself full-heartedly. In this way, when David enters Giovanni's room for the first time, he carries with him this ambiguity of emotions. 
During their first night together, when Giovanni pulled David into his arms, everything in him screamed "No! yet the sum of [him] sighed Yes" (87; Baldwin's italics).

Thus, David's tragic experience is intrinsically connected to Giovanni's room, which David sees at the beginning of their relationship as a sanctuary. David remembers that "time flowed past indifferently above us" in this room in which their "joy and amazement was newborn every day" (99). However, upon Hella's return to Paris, David decides to marry her in order to save his "immaculate manhood," and he tells Giovanni that he feels the "hideous room" (155) like a prison cell he has been kept in. Hella takes on the notion of the "familiar, darkened room in which [David] tried to find the light" (161). He suggests to her that they leave Paris. However, in the big house which David and Hella rented in Southern France, David eventually realizes that "the nightmare of this house began...[because he] found her body uninteresting, her presence grating...[he] felt his flesh recoil,...and whenever [he] entered her [he] began to feel that [he] would never get out alive" (208). It is this recognition, I think, which makes Baldwin's tragic protagonist take on heroic dimensions. He came to realize that "the key to [his] salvation, which cannot save [his] body, is hidden in [his] flesh" (223). He acknowledges that if he had not been "too various to be trusted", he would not have been alone in this house, Hella would not be on the high seas to America, and Giovanni would not be executed (10; italics mine). David accepts these losses through the awareness of his mistakes. The tragedy in Giovanni's Room stems from a dynamic collision of equally justified causes -David's attempt to conform for fear of the society and his genuine love for a man. David finally sees that "people can't invent their mooring posts, their lovers and their friends, 
anymore than they can invent their parents. Life gives these and also takes them away and the great difficulty is to say Yes to life" $(10)$. He truly and desperately repents all his lies. And he recognizes the ironic trick life played him by telling all these lies, by running away from America and the memory of Joey only to find out that the same destiny awaited him in France. Nonetheless, David in the end qualifies as a tragic protagonist because he finally faces his destiny -- a homosexual life -- with courage and nobility of spirit and steps into the morning of Giovanni's execution "with the dreadful weight of hope on his shoulders" (224).

Claude J. Summers appropriately describes Giovanni's Room as a penetrating study of self-deception and an unsentimental study of homosexual life in the 1950s. He says that this Baldwin novel is distinguished for its social approach to the question of homosexuality. Summers explains that although Giovanni's Room is framed as a coming-out story, it is also a "problem novel" because it recognizes the homosexual dilemma as a socially significant issue. Through the placement of David's fate within the broad context of American values, Baldwin both reflects and challenges the sexual attitudes of his time (128). However, as much as Giovanni's Room represents the homophobic tenor of the Eisenhower years through these ambivalences in the text, it also vividly mirrors, and there I agree with Summers, the social reality of that time by means of the divided and deceitful self of the protagonist David.

Giovanni's Room is in itself one more critique of American attitudes. As Baldwin conveys through the elder homosexual Jacques: " But the way to be really 
despicable is to be contemptuous of other people's pain" (75), and this is true for any people.

Giovanni's Room is Baldwin's reaction to the social and legal prohibition of homosexuality; it is essentially defensive and yet affirms a homosexual identity. However, Baldwin's adherence to popular societal beliefs about the causes of homosexuality and his principally negative ending of this novel, in that he cannot picture a positive future for a homosexual couple, lead me to the conclusion that at this point in his fictional career he has not yet achieved a positive acceptance of homosexuality in his novels. David at one point in the novel contemplates what his future would be as a gay man when he would not be with Giovanni anymore. And this thought creates hatred in him for Giovanni who had awakened that "beast" in him which "would never go to sleep again" (111) because he asks himself: "Would I then, like all the others, find myself turning and following all kinds of boys down God knows what dark avenues, into what dark places" (111)?

Like all of Baldwin's novels, Giovanni's Room is very complex, and although it is clearly a homosexual novel judged by the content itself, Baldwin so skillfully maneuvered the topic that his stand on it could be read in several ways. Again, we can say that Baldwin played it safe because he created sufficient ambiguity in Giovanni's Reom, allowing multiple interpretations, which include also anti-gay interpretations.

Mark Lilly in Gay Men's Literature in the Twentieth Century accuses Baldwin, for example, of a "special, and especially repellent, kind of homophobia of which Baldwin is guilty time and again" (164). He argues that Baldwin considered himself a 
"straight-acting" gay man who displays a kind of unique homophobia meant as a plea to the heterosexual majority to consider him and others like him as entirely "normal" based on a rejection of the effeminate. Lilly exclaims that the "'straight-acting' gay man asks for acceptance from straight society, and the price that he thinks might be sufficient for this is betrayal of his fellows" (164). He cites as an example the following passage:

There were, of course, les folles, always dressed in the most improbable combinations, screaming like parrots the details of their latest love affairs...I always found it difficult to believe that they ever went to bed with anybody, for a man who wanted a woman would certainly have rather had a real one and a man who wanted a man would certainly not want one of them (38; Baldwin's italics). Or Giovanni, who is one of the "straight-acting" gays in the novel, describes Guillaume as an "disgusting old fairy" (141).

Readers who did not want to acknowledge the novel's or the writer's significance within the canon of gay literature saw the French setting as Baldwin's tactic to remove himself from the plot and defined Giovanni's Room as an anti-gay novel because of its realistic and thus simultaneously unattractive and sad picture of the gay subculture. The French setting could serve as a metaphor for homosexuality being foreign in a sense and thus also represent a distancing technique of Baldwin's. There are some ambiguities to be found in this novel, which, as Claude J. Summers observes, might have served as the author's devices for self-protection during an era of extreme homophobia and thus permit also anti-gay interpretations. He sees this accomplished by Baldwin through a sexually confused and unreliable first-person narrator, his unattractive and decadent 
description of the homosexual milieu, and the melodramatic frame of murder and execution (173).

In an interview Richard Goldstein conducted with James Baldwin in 1984 and in which he specifically asked him about homosexuality, Baldwin said that the best advice he ever got was from an old black friend who said "you have to go the way your blood beats. If you don't live the only life you have, you won't live some other life, you won't live any life at all. That's the only advice you can give anybody. And it's not an advice, it's an observation" (185).

I read the finishing lines of Giovanni's Room in this light. A homosexual relationship in this novel has not yet a chance for a positive future. Yet, David, after paying a high price, is finally ready to 'go the way his blood beats' and this is why he feels the "dreadful weight of hope" on his shoulders when he steps into the awakening morning, a symbol in itself of a new beginning. And with this conclusion the author of Giovanni's Room has also set the tenor for his subsequent novels. 


\section{CHAPTER IV}

\section{ANOTHER COUNTRY -- THE TURNING POINT}

Rather than discuss Another Country in detail, in this chapter I shall focus on some of its main points to show significant changes in Baldwin's perception about homosexuality, beginning with this novel. Yet again, the central plot of the book, which is intimately linked to jealousy, lust, ambition, failure, hate, and racism, evolves more around the universal topic of love than homosexuality. The fragility of love is a constant theme. Love, or the absence of it, becomes in Another Country a much more serious issue, and its ramifications are depicted within the context of interracial relationships. Leeming asserts that Baldwin confronted sexual and racial issues in Another Country that hitherto had been virtually ignored in American literature. Baldwin himself suggested, as Leeming tells in the biography, that Americans found the novel worth reading because they were more like the people in the novel than they had dared to admit to themselves before (208).

The first seventy some pages of the novel tell the story of the demise of the young, black jazz musician, Rufus Scott, in New York's Greenwich Village. Although Rufus commits suicide at an early stage of the novel, his spirit haunts the remainder of the plot and is the trigger for all the actions. The main body of Another Country takes 
place after Rufus' death. Vivaldo Moore, a young white bohemian and Rufus' best friend, and Ida Scott, Rufus' sister, are basically the central figures of Baldwin's novel; but for my specific homosexual reading of it, they are not so crucial. In the development of the plot Ida has an affair with the white television producer, Steve Ellis, for an advancement in her singing career. The other main characters are Eric Jones, a Southern white homosexual; his French lover, Yves; and the married white couple, Cass and Richard Silenski.

By making Vivaldo Ida's lover, Baldwin creates an interracial relationship and brilliantly displays the tensions that accompanied the mixing of races in the 1960 s, which he also describes earlier in the plot through the eyes of Rufus when he walked in the streets with his white Southern girlfriend, Leona. Cass and Richard, the other heterosexual couple, have been married for a long time and have two children, but experience difficulties in their relationship. Eric, a young American from the South, comes from a rich and very conservative background. As a child he was infatuated with their black housekeeper. He had as a teenager an affair with a young black man from his village and was Rufus' lover when they both were young. The French Yves is introduced as Eric's current lover.

Eric, who is essentially homosexual, has a sexual affair with Cass after his return to the United States and in the absence of his lover, Yves, who is still in France. Eric also has sex with Vivaldo during that time, comforting and empowering Vivaldo whose relationship with Ida is about to dissolve. After this experience Vivaldo comes to the recognition that he might have saved Rufus' life, if he had overcome his hesitations and 
made love to him, because he believes that Rufus' homosexual affair with Eric in their youth was more satisfying to Rufus than any other relationship. In this way, most of the important male characters are involved in bisexual, and in some cases also interracial, activities.

Mark Lilly in Gay Men's Literature in the Twentieth Century sees love as the cause for the anguish recorded in Another Country. He established a list of the sexual pairings in this novel which seems very helpful to me for a clarification of the plot (149):

Rufus - Eric (gay relationship, short-lived, Rufus less sexually interested) Eric - Yves (idyllic gay relationship)

Eric - Cass (gay/ straight; experimental for both; short-lived)

Eric - Vivaldo (gay/ straight; experimental for both; one day) Cass/ Richard (boring marriage)

Ida - Vivaldo (straight, troubled, plagued by jealousy and lack of trust) Ida - Ellis (Ida sleeps with Ellis for social/ financial advancement) Vivaldo - Jane (stormy rupture after racist remark by Jane)

Rufus - Leona (physical violence; ends in suicide and madness respectively)

Already a brief look at this very abstract list exhibits two overriding themes of the novel: relational instability, and the enormous variety of sexual experience open to human beings, if only they dare to affront conventions (Lilly 149).

Another Country marks the turning point in James Baldwin's treatment of homosexuality in his novels, which I will illustrate through four different points. 
First, I would argue that Baldwin has in this book completely freed himself from Freudian and other common perceptions about the origins of homosexuality and does not try to present any justification for it. The absence of mothers and fathers who are domineering, weak, or bullying in contrast to the preceding novels, Go Tell It On the Mountain and Giovanni's Room, clearly indicates that he had come to accept the naturalness of homosexuality. Baldwin, in a dialogue between Cass and Eric, conveys that he is highly aware of psychological explanations for homosexuality: "That's not the usual pattern, is it?...I mean, from what we are told, most men with a sexual bias toward men love their mothers and hate their fathers" (245). However, the non-appearance of the above described pattern in the depiction of any of his characters displays, in the context of prior usage, his abandonment of these justifications for the origins of homosexuality.

Second, Baldwin idealizes the homosexual theme in Another Country and elevates the homosexual relationship between Eric and Yves above all the heterosexual relationships. In comparison to Giovanni's Room, the homosexual relationship between Eric and Yves is endowed with Edenic images when first introduced in the book, and it is the only relationship characterized by happiness and with a positive future perspective. This constitutes a major jump in relation to the preceding novels.

The idyllic relationship Yves and Eric experience in a vacation house in France has been commented on as unrealistically blissful by many critics. This 
isolation, which makes their felicity possible, implies again that gays cannot be at ease in public. Moreover, this idyllic setting in a warm, Mediterranean garden suggests provisional rewards of a hard-won relationship between Eric and Yves based on love and trust. Stephen Adams argues, and I full-heartedly agree, that the sentimentality and romanticism of these moments are justified, because their time at the vacation house is only temporary and precedes Eric's journey to New York (49). "In order not to lose all that he had gained, [Eric] had to move forward and risk it all" (159).

Furthermore, Mark Lilly observed that Baldwin in depicting this idyll in France made use of the Western cultural tradition of binary oppositions between the city and the country. He explains, that Baldwin perceives America as the city which is traditionally characterized by vice and virtue, whereas France represents the country, endowed with a 'pastoral myth of idyllic happiness in pleasurable penury'(156). Lilly sees a clear distinction between America and France. While there is generosity, human warmth, and beauty to be found in the experience of living in France, America is associated with pain, anguish, racism, and urban ugliness. On the metaphorical level Baldwin demonstrates that same-sex lovers can achieve personal fulfillment and that it is societies and cultures that prevent human flourishing. Thus, Lilly concludes, the artistic purpose of the book is to present a happy gay couple in the surrounding homophobic culture, a technique which is called today presenting 'positive images' (157). Lilly's assumption is, in my opinion, justified. Eric has become an existentialist after encountering "an 
army of lonely men who had used him...[and] had made him the receptacle of an [unbelievable] anguish "(179) in a loveless and homophobic society. Tired of relations without love, affection, or confession, and of satisfying other men's needs, "which they spent their lives denying...in the shameful, the punishing dark "(180), Eric recognized that he needed to create his own standards if he wanted to find out his own identity in this chaos, and thus, he formulates his own existentialist position:

He knew that he had no honor which the world could recognize. His life, passion, trials, loves, were, at worst, filth, and, at best, disease in the eyes of the world, and crimes in the eyes of his countrymen. There were no standards for him except those he could make for himself. (181)

This is why Eric goes to France whose people do not judge Eric "by [its] civilized standards" because "France did not, Dieu Merci! produce such conundrums as Eric" (181; Baldwin's italics).

I agree with Emmanuel S. Nelson in that he considers Baldwin's stand on homosexuality -- his need to show the superiority of the homosexual over the heterosexual -- polemical and defensive, a sign that Baldwin has not yet come to a healing acceptance of homosexuality in his literary imagination. However, I regard the positiveness with which the homosexual acts and relations are depicted as a great progression in Baldwin's acceptance toward homosexuality in his novels. Indeed, the heterosexual relationships in the novel are endowed with elements of repression, surrender, bitterness, and, in general, negativity. 
Leona, for instance, repeatedly and from their first encounter on, submits to Rufus' physical and psychological abuse which eventually leads to her insanity: Tears hung in the corners of her eyes...and in spite of himself [Rufus] began moving faster and thrusting deeper. He wanted her to remember him the longest day she lived....Under his breath he cursed the milk-white bitch and groaned and rode his weapon between her thighs. She began to cry. I told you, he moaned, I'd give you something to cry about.... A moan and curse tore through him while he beat her with all the strength he had and felt the venom shoot out of him, enough for a hundred black-white babies. (24; Baldwin's italics)

Similarly, Cass develops bitterness toward Richard, her husband of Polish descent, because she had been heavily disappointed that he turned into a mediocre novel writer to earn the money for their living; however, she must admit that she had helped him to become what he is. She also comes to recognize that during their marriage she had been reduced to being a mother of their two sons and good wife to Richard. She seems to have lost all her sexual attraction for Richard and thus with it lost the sense of being a desirable woman instead of merely an obedient house wife.

The third major heterosexual relationship between Vivaldo, Rufus' best friend, and Ida, Rufus' sister, is also strained because Ida continuously accuses Vivaldo of not understanding the real causes for Rufus' death, resulting from his race, and she keeps reminding Vivaldo of her color and blaming him for his 
whiteness. Ida is determined to progress in her career as a singer, and this is why she 'sells' herself by secretly having an affair with the successful TV-producer, Steve Ellis. After Ida's confession about her amour with Ellis, Vivaldo did not know how to live with the truth he so long had kept avoiding. "He looked over at her, and a wilderness of anger, pity, love, and contempt, and lust all raged together in him. She, too, was a whore; how bitterly he had been betrayed" $(361) !^{16}$

Third, most of the male characters in Another Country are not exclusively homo- or heterosexual but engage in bisexual activities. Thus, by refusing to categorize human beings as homo- or heterosexuals by having most of his male characters engage in bisexuality, Baldwin voices his concern about the stigmatization of humans. Nelson in his article "The Novels of James Baldwin: Struggles of Self-Acceptance" sees proof for Baldwin's heightened maturity by having such basically very masculine characters as Rufus and Vivaldo engage in homosexual activities and thus challenge the notion of homosexuals as effeminate and limp-wristed (14). Mark Lilly in Gay Men's Literature in the Twentieth Century assesses that the homosexual acts of the heterosexually oriented men are constructive interludes in their lives, which is almost the exact opposite of the prevalent psychoanalytic view (159). Baldwin's positive outlook on homosexuality makes Another Country so unusual. Baldwin's larger point, though, is to demonstrate the importance of love which can assume many forms. The acceptance of love in all its variations leads to a heightened maturity and 
growth of the characters. Eric takes on the role of a redeeming figure in Another Country. His sexual activities with various men are very positively described. Vivaldo feels "clear, washed, and empty...[full of] peace and gratitude" (325) after having sex with Eric. His interlude with Eric frees Vivaldo from the 'manly shame' that had held him back and brings him to the recognition that he might have saved Rufus, if he had taken him into his arms during the last night he saw him. Yet, he had not been able to do so because "[he] was afraid that [Rufus] wouldn't understand that it was - only love. Only love" (289; italics mine). The encounter with Eric also prepares Vivaldo who has been in despair over Ida to face their problems. Eric explains to Vivaldo that once one is able to accept and use the pain which seems to kill one, then life will become better. Only then life won't cease; otherwise "you can't move or change or love any more" (329). With this knowledge Vivaldo might be able to accept Ida's betrayal because his love for her is stronger than his pain, and although Baldwin leaves their future open-ended, they have reconciled at the end of the novel.

Cass realizes her own authority and thus gains a renewed sense of herself and, in this way, a sense of liberation through her sexual affair with Eric. Through jeopardizing everything, Cass has professed that she is trying to live the way she thinks she ought to live again, trying to walk out "that empty life, that meaningless life" (293). As she tells Vivaldo: "No thank you, I don't want to be protected anymore" (271; Baldwin's italics). 
Fourth, I consider it a progression that Baldwin envisions a continuation of

the homosexual relationship in America that was initiated in France. In

Giovanni's Room the entire action took place in France, involving an American

and an Italian. The homosexual protagonist, David, left America to find out about his sexual identity in a less restricted European society. Perhaps we could interpret that as a suggestion of Baldwin's that homosexual relationships are only possible outside America. However, Another Country ends with Yves' arrival at the airport in New York. Met by Eric, "[Yves] strode through the barriers, more high-hearted than he had ever been as a child, into that city which the people from heaven had made their home" (366). Stephen Adams wonderfully explains that Yves symbolizes the messenger who descends from the skies to bring the message of hope through his arrival in the last section of the book, entitled 'Toward Bethlehem' (53). Everything in this ending suggests that their relationship will be successfully carried on in America. Eric, who "looked very much at ease, at home,...with his short hair flaming about his head" (385), assures in Yves the feeling "that everything would be all right" (366). Eric is endowed with this positive flair because he also has been strengthened by his encounters with Cass and Vivaldo. The affair with Cass gave him a last chance to opt for safety and to escape the fear inherent in his love for Yves; the fear that the younger Yves might not need him any longer one day and will drop him back into the underworld. Eric's encounter with Vivaldo proves to both of them that each is worthy of love at a time of despair and danger of succumbing to sexual fears and guilt. Vivaldo 
leaves Eric with new courage to meet Ida, and Eric has overcome his anxieties New York had reawakened in him. Thus, it seems completely justified that the protagonists are reunited in the United States, whereas the preceding novel ended with David standing alone in the cold winter morning in France.

Through Eric, Baldwin voices his continuous request for the need to understand the importance of love which the other characters come to learn through Eric. When Vivaldo tells Eric, "I certainly think that the real ball game is between men and women. And it's physically easier" (285), Eric responds that love always finds a way. In the same dialogue the issue of the family is addressed, which, in my opinion, represents another progression on Baldwin's side. In comparison to Giovanni's Room, I think, he has moved away from his previous stance that it is exclusively homosexuals that are a threat to happy family units. Communication matters, not one's sexuality. Eric declares that it takes only five minutes to make children, "and you haven't got to love anybody to do it. If all the children who get here every year were brought here by love, wow! baby, what a bright world this would be (285; Baldwin's italics)!

Baldwin attempts to show through Another Country the necessity of risktaking and transgressing the boundaries by breaking down the categories of race and sexuality. His characters combat with vulnerability, shame, strength, courage, and toughness society's definitions and their own internalized shame. This is why I agree with Lilly in calling Baldwin an existentialist because he believes that people can transcend the "given", the customary and the conventional -- indeed, 
they must do this -- and "find themselves" through individualistic, dangerous and daring ways (Gay Men's Literature in the Twentieth Century 150). Yet, Stanley Macebuh in James Baldwin: A Critical Study considers the presentation of the homosexual hero, Eric, despite Baldwin's bolder treatment of homosexuality in Another Country, as a not very convincing vision, and there I partially agree with Macebuh, because Baldwin seems to be more concerned with the salvation of individual souls than the health of the community (154). However, I think that the reformation of a society begins on a small scale, and already Baldwin's depiction of a character like Eric evidences his ongoing concern with society. Eric, Cass, and Vivaldo will be forever connected through these experiences, and, in my opinion, Baldwin wants to convey that if there were more Erics in a society, one might still hope for a better, "another" country. Baldwin's development of the homosexual hero whose redeeming powers move from individuals to an AfroAmerican community will be witnessed in my last discussed novel, Just Above My Head, through the protagonist, Arthur.

The above discussion barely touches on the complexities of Another Country. What I wanted to convey, though, is that Baldwin has for the first time in his novels given a very positive, even idealized picture of homosexuality. This idealization indicates that he felt the need to defend a functioning homosexual relationship, given the homophobia still prevalent in American society in the sixties. Moreover, Another Country manifests Baldwin's protest against any kind of labels created by society. This is why love, the virtue of ultimate significance, takes on many forms in Another Country, regardless of 
social mores, ethnic backgrounds, or national origins, and refuses confinement to the narrow limitations symbolized by the conventional terms "homosexuality" and "heterosexuality."

Baldwin himself explained that the characters are on a desperate search for the self-knowledge and self-esteem without which real love is impossible. Without such love people are unable to learn to see real human beings behind the categories, labels, and prejudices created by the loveless, and the horrifying results of such blindlessness are evident in the history of the twentieth century. Another Country, said Baldwin, is not pornographic; rather it is an attempt to break through cowardly and hypocritical morality. (qtd. in Leeming: 200). 


\section{CHAPTER V}

\section{JUST ABOVE MY HEAD -- END OF THE JOURNEY}

James Baldwin's last novel, Just Above My Head, is -- in my opinion -- the best of the novels discussed in my thesis. It is a brilliant synthesis of the issues that have concerned Baldwin his entire life, presented here with both anger and passion. $\underline{\text { Just }}$ Above MyHead picks up the familiar themes of religion, alienation, racism, and sexism in the American scene, but above all it is concerned with the black family, brotherhood, and community. Arthur, the homosexual hero, functions as a redemptive figure on a communal level in this novel, in contrast to the individual heroism of John in Go Tell It On the Mountain, David in Giovanni's Room, and, to some extent, Eric in Another Country.

However, many critics do not share my enthusiasm. They evaluate the novel as a mediocre story filled with lifeless and unreal characters. James Levin, for example, finds that Baldwin's characters are wooden and that the work fails to display the development of viable homosexual relationships. Levin also considers it a flaw that neither one of the homosexual characters ventures into any part of the gay subculture (302).

But to me, Just Above My Head, which ends Baldwin's novel writing career, also represents the end of his journey toward a healing acceptance of homosexuality. In 
reference to the two stages of coming-out as described by Diana Fuss, Baldwin's last novel symbolizes the integration of homosexuality into one's life. Baldwin had labored with and progressively resolved the question of accepting oneself as homosexual, as I have shown in Go Tell It On the Mountain, Giovanni's Room, and Another Country. In Just Above My Head Baldwin is able to view calmly the joys and agonies of homosexual life because he has come to terms with his sexual self.

Baldwin's novels are repeatedly retrospective. Dorothy H. Lee in her essay, "The Bridge of Suffering," explains that the past is revelatory for protagonists who, through memory, come to understand their suffering. We saw this process in Giovanni's Room where David, through a re-evaluation of the past, comes to understand and accept what happened in it. In Just Above My Head we learn, mostly through the narrative voice of Hall Montana, about the life of his homosexual brother, Arthur, who became a famous gospel singer and died at the age of thirty nine in a bathroom in London. The novel opens with Hall who, two years after Arthur's death, realizes that "I was so busy getting my brother into the ground that I've hardly had time to cry, much less talk"(23), and so he takes himself and us back in time to recount the succession of events. The main plot engages with the lives of two Afro-American families, the Montanas and the Millers. Paul and Florence Montana, the parents of Hall and Arthur, are befriended by Amy and Joel Miller. The Millers have two children; Julia, a child evangelist, and her younger brother, Jimmy. Amy and Joel put Julia on a pedestal, because she has been a successful child preacher and guarantees the family's income, whereas Jimmy grows up unloved and neglected in the shadow of his sister; after his mother's death Jimmy is sent to the South 
to live with his grandmother. Julia gives up preaching after her mother passes away and lives with her father; an incestuous relationship develops between them. After a miscarried pregnancy, most likely by her father, Julia is also sent to New Orleans to stay with her grandmother. A few years later Julia is offered a job as a model, which enables her and Jimmy, after their reconciliation, to return to New York where they come back together with Hall and Arthur.

Parallel to these events, through alternating chapters, the story of Arthur is told. Arthur forms with his friends, Peanut, Red, and Crunch, a gospel band called the Trumpets of Zion. During their first trip to the South a homosexual love relationship grows between Arthur and Crunch. After their return from that trip, and shortly before Crunch is drafted into the Korean War, he meets Julia again who by then has "hit the street." A short sexual affair takes place between them while he is still together with Arthur. After returning from Korea, Crunch is plagued by his love for Arthur, but his fear of having a male lover and his indecisiveness lead Arthur to break up with Crunch. Later Arthur unexpectedly meets Jimmy, Julia's brother -- whom he had known since childhood -- in New York, and they realize their mutual affection. Without knowing it, they have only one night during which the beginnings of a long relationship are initiated. Business separates them for two years before they meet again. During that time Arthur has a short and stormy affair with a French man, Guy Lazar, while staying in Paris, which eventually prepares him for Jimmy. Upon his return to the U.S. a relationship forms between them which lasts fourteen years until Arthur dies of a heart attack while in England. 
Through retelling Arthur's story, Hall Montana also comes to understand himself. He realizes why he was not able to commit himself to his girl friend, Martha, before he went to Korea; and he reflects on his impassioned affair with Julia until she left for Africa. This relationship prepared him for his love for his wife, Ruth, and he and Ruth have two children, Tony and Odessa. Hall is very content with his life. Yet, because Hall was Arthur's older brother, his protector, and eventually his manager, he becomes aware that with Arthur's death he has lost one great part of his life and love, and so his story is at the same time celebrating and mourning Arthur's fate.

The dignity and the pathos with which James Baldwin describes homosexuality in Just Above My Head exemplify his awareness of and desire to depict homosexuality as a normal variation of human behavior. Unlike in his other novels, he does not suggest homosexuality as an underlying issue or idealize it, but weaves homosexuality naturally and gracefully into the plot. The coming into being of relationships between homosexual characters in Just Above My Head is rendered with the same passion and sensibility and endowed with the same beauty and painfulness as any other love relationship. There are two parailel scenes in the text which picture the sexual act between Julia and Hall with the same intensity and warmth of feeling as between Arthur and Jimmy. Thus, Baldwin does not distinguish between the different kinds of sex or elevate one over the other, but again demonstrates that it is only love that matters. Yet love, as the novel reveals, is often filled with pain, Baldwin's reiterated paradox.

Just Above My Head clearly contains the elements which characterize the discourse of homosexual experience as defined by David Bergman. Arthur, the main 
homosexual character around whom the plot evolves, has three relationships in his life: the failed youthful relation with Crunch; the brief but successful relationship with Guy Lazar in Paris; and the fourteen year relation with Jimmy. Each relation testifies that homosexuality is a lifelong condition and not just a phase.

There are three factors which most crucially indicate to me that James Baldwin had come to a healing acceptance of homosexuality in his literary imagination. First, referring back to David Bergman's terms describing the discourse of homosexual experience, we recall that Bergman speaks of a profound sense of otherness as the most significant term affecting the homosexual. Taking the novel by itself and the naturalness with which homosexuality is intermingled with other elements in the plot, we do not, in my opinion, encounter this notion of alienation and otherness about sexuality. Baldwin tells us in Just Above My Head the moving stories of developing relationships, and some of them are between men and women, and some are between men and men. Yet their depiction and their value are equal in the sense that no one relationship is elevated above the others, bringing forth Baldwin's absolute and repeated stance for the importance of love and against the labeling of people.

Second, in this novel James Baldwin seems no longer to adhere to Freud's theory that homosexuality is the entrapped sexual development of an adolescent. Leeming explains that in Just Above My Head Baldwin celebrates, almost allegorically, the ability to overcome the barriers of gender in the interest of genuine love between individuals, and his belief in love as the basis for the artist's 
“song" (347). Thus, Baldwin wonderfully wraps Arthur's sexual development into the metaphor of the song; the more content Arthur is with his life, the better his song becomes. Arthur's father said that “Music don't begin like a song....Music can only get to be a song, but it starts with a cry" (80). The cry is one of pain, and the movement from sound to music proves that love is in the world.

Arthur's first sexual experience with an unknown man, which frightened him but also awakened his curiosity, falls into the beginning of his singing career. It is symbolically the birth cry for his homosexual life. From then on his songs and his life are intrinsically connected forever. Julie Nash in her brief but penetrating study, "A Terrifying Sacrament": James Baldwin's Use of Music in Just Above My Head," sees music as a metaphor for "loving right" and "living right." As Arthur tells his brother, Hall, "I've got to live the life I sing about in my song" (61), a song which reminds us,

If you live right,

Heaven

Belongs to you,

If you love right

heaven

belongs to you. (388)

Thus when Arthur, at the beginning of his sexual awakening, feels a "tormenting need, with no name, no object" (180) rise in him, he begins to feel 
lonely because his family who loves him is not enough, cannot be enough to fulfill his sexual desires. "For the moment, the song is enough -- almost enough: everything, or almost everything, goes into the song" (180). This line indicates that the "song," more than just advancing the plot, symbolizes a way of life -- "of living right and loving right and surviving seemingly insurmountable odds" (108). Music is the catalyst for Arthur's development from a gospel singer to a civil rights fighter to a star, and his closest friendships and love affairs are with other musicians. Crunch and Arthur's relationship develops with the song, and so their playing together precedes their sexual relationship. "Crunch and he were moving together, here, now, in the song, to some new place" (198).

Paris represents a significant period in Arthur's career for his sexual selfacceptance. Once more, as in Giovanni's Room and Another Country, Baldwin removes the plot from the American scene at a crucial point. While in Paris, Arthur has a brief but intense relationship with Guy Lazar whom he had met at a cafe. With Guy he lays down part of his burden of fear and shame. Arthur in Paris does not feel the restraints or anxieties about his sexual life, that he does in the U.S.. His past seems to drop away, everything "falls away, all, but the song he is as open and naked and questing as the song" (461; italics mine). And what he learns from Guy, and with Guy, he is able to translate into his song -- his love and his life -- with Jimmy. Through his absence from the American scene Arthur is able to look at things with a freedom he did not feel in America. In America, Arthur had 'put to sleep' his homosexual desire after he and Crunch split. Yet, 
this affair with Guy in Paris is 'loving and cleansing'(Lee 95), it creates a reawakening of Arthur's sexuality promoted by his sense of liberty in Paris. Guy seems to drain off the pain in Arthur, which stems from his prior racial, artistic, and homosexual experience. He diminishes Arthur's fear of his own identity and makes his self-acceptance possible. Arthur achieves happiness in Paris because he has made Guy happy. Like David in Giovanni's Room, Arthur gives Guy hope "to live again" (493). At the same time Guy helps Arthur to shake off his sexual and spiritual anguish and restraints and thus, upon his return to America Arthur "knew, somehow, that he was certain, now, to see [Jimmy]" (503).

It is through Jimmy, then, that Arthur becomes a star. Jimmy's presence in Arthur's life, Jimmy's love, "filled his voice with multitudes, summoned, from catacombs unnamable." Together, as singer and pianist, they accomplish "mysteries which neither could dream of confronting alone" (539). This is because, as Jimmy puts it, "[t]he singer is found by the song" (552). He hears something, and that something he makes into a song. And Arthur's songs become perfected when he finally lives the life he sings about in his songs. He once said to Hall that "he could not afford to live a lie" (244), and he becomes a star when he has achieved his true self, when he finally manages to "live right" and to "love right" (388). As Julie Nash phrases it, Arthur and Jimmy team up musically when they fall in love with each other, and the music is temporarily able to lift them out of despair (italics mine). Hall observes that "[i]f they could play this way together, they would certainly be fools to lose each other now" (518)! Their 
musical collaboration is the confession of their love, and this love is made sacred by its connection to music. Hall recalls that the song "Just a Closer Walk with Thee" became "a sacrament, a stone marking a moment on their road: the point of no return, when they confessed to each other, astounded, terrified, but having no choice, in the hearing of men, and in the sight of God" (539).

The third indication of Baldwin's acceptance of homosexuality is that similar to Another Country Baldwin makes no reference to the psychoanalytic theory of strong mothers and weak or bullying fathers as the cause of the developing son's homosexuality. To the contrary, Baldwin describes the Montana family as very loving, caring, and supportive of their children. Arthur was hesitant about his coming-out because he did not want to hurt or worry his family whom he loved so much. Yet, his mother, Florence Montana, with a mother's sensitivity, knows from Arthur's demeanor -- his glowing face at Crunch's appearance-- about her son's homosexuality. And yes, it worried her as a mother would always worry about her child's fate, identity, and future; as much as she would have been worried if Hall decided to marry a white girl (244). His father, Paul, teaches him to sing and to play the piano -- it is the music that connects them and which is the means into which Arthur carries all his love, desires, and pain. It is through the song that father and son can talk about Arthur's homosexuality without directly addressing it. Arthur hated to have anything to hide before his parents whom he loved and who loved him and so "he poured it all into his song, and Paul watched him, and listened, striving to become reconciled" 
(263). I think, the most marvelous proof that Arthur was fully integrated into the Montana family, and that they wished above all for Arthur's happiness, is that Tony, Hall's son, was conceived at what Hall calls the "tremendous moment in all our lives,...the turning point" (538) when Jimmy and Arthur finally came together. The birth is a symbol of new life for Jimmy and Arthur.

Once more, in Just Above My Head the genuineness of the homosexual experience is depicted through the heartfelt desire of gay men for men, in contrast to an absence of these feelings for women. Thus, Arthur feels tormented and panic stricken when a sister approaches him in church, indicating to him that she likes him. He is still too young to know much about love or sexuality; he is in the very beginning of his sexual awakening, and yet feels that "he does not want to do that" (180; Baldwin's italics). However, he remembers how a man took him off the street when he was thirteen and started to perform fellatio on him: "it was the way he made [him] feel about [himself]...he filled [Arthur] with a terrible curiosity" (61). This occurrence was the beginning of a growing voice in Arthur telling "him that he is not for her" (181) and not for any woman. And indeed, Baldwin does not present any women in Arthur's sexual life.

Homosexuality is also marked by the equality of its relations in $\underline{\text { Just }}$ Above My Head. This is realized through the avoidance of particular roles given to individuals in various areas. First, there is no specific sexual role assigned to the male lovers in the novel: Both partners assume the role of the receiver and penetrator equally. This is the case in all three of Arthur's relations. Moreover, 
the homosexual relationship between Guy and Arthur cuts across racial boundaries, since Arthur is black and Guy is white, and across cultural boundaries in terms of French and American culture.

In Just Above My Head Baldwin once again mirrors the effect of societal prejudice upon individuals through the characters of Crunch, Arthur, and, after his death, Jimmy. Entrapped in public beliefs, Crunch revolts against his natural feelings. This is why he is not able " to deal with the implications in his life as a man of having a male lover" (335). Crunch was afraid that Arthur could only devalue his manhood, and he was afraid that he did the same to Arthur. Yet, more than once "Crunch, at the absolute limit of his endurance, no longer able, simply, to contain it...pulled Arthur into his arms" (447). Afterwards, his happiness was written on his face and it seemed to mightily relieve him to tell Arthur how much he loved him. More than satisfying, though, this situation is tormenting Arthur and Crunch because Crunch is not able to accept his homosexuality and to carry it into the public. Arthur eventually breaks the relationship, and Crunch ends up having one girl friend after another because "he wanted some unassailable corroboration of his manhood" (447).

Jimmy had not cared what anybody said or thought when he and Arthur were together simply because Arthur's love had made him happy. Thus, Jimmy furiously tells the reader that only after Arthur had died had he felt unhappy because "all the other moral shit, what the world calls moral, started fucking with my mind" (551; Baldwin's italics). 
The tone with which the narrative voices scrutinize and criticize the society, I think, has dramatically changed between Baldwin's former novels and this one, and Just Above My Head contains a lot more anger, bitterness, and frustration, but also cynicism with regard to homosexuality. Baldwin in one of his many essays said that people invent "faggots" so that they can sleep with "straight cats," having in mind the necessary sense of order and security Americans always strive for. In Just Above My Head he goes beyond the acceptance of homosexuality in order to show his larger critique that sex without love or spiritual communion is destructive. White, heterosexual Americans feel guiltless and hence blameless if they have somebody to look down on, which is why they create categories like "the homosexual." Baldwin mocks the hypocritical society because he has experienced its double-edged morality himself. He was baffled and hurt to be called in public "faggot" by men who yearned to make love to him in private. Through Hall, for instance, he articulates this bitterness at the opening of the novel, conveying that one's sexuality is one's private affair and that it is society that creates the problems:

I once heard myself shouting at some asshole white producer, who was giving me some mealy-mouthed crap about my brother's life being a problem, If he likes boys, then buy him a bathtubful, you hear? Buy him a boatload! What the fuck do you like? I'll never forget that cat's face: some people look at you like you've farted when you try to tell them the truth, or when they know you mean what you say. (22; Baldwin's italics)

Furthermore, through Hall Baldwin voices his critique of homosexual or heterosexual relationships that are mechanical. At the time of Just Above My 
Head Baldwin is accepting homosexuality enough to be publicly critical of some practices. In a conversation Hall has with his teenage son, Tony, after Tony admits that the kids in school called Arthur a "faggot," Hall reminds his son that he and Ruth have raised their children "not to believe in labels" (37). Through his confession that he himself, Hall, had had sex in the army with men, Hall emphasizes that not what you do or did, but who you are, is important. He says that he is proud of his brother, because despite what his brother was, "and he was a whole lot of things, he was nobody's faggot" (37). A "faggot" is somebody like Mr. Webster, the manager who accompanies the Trumpets of Zion quartet to the South (212). Crunch calls him that after Webster, realizing that something was going on between Arthur and Crunch, asked Crunch for sex. Indicating that he knows what they "are doing," Webster tries to blackmail Crunch for physical pleasure. He attempts to turn the love between Arthur and Crunch into a perversity. Yet, Arthur and Crunch are two "singers" literally and metaphorically who live out one of Baldwin's most important messages -- "that without love, pleasure's inventions are soon exhausted. There must be a soul within the body you are holding, a soul which you are striving to meet, a soul which is striving to meet yours" (310). This is why Mr. Webster, despite his threat to separate them if he does not get what he wants, is unable to destroy their "song," which is stronger than his corruption.

This message that love and having sex are not synonymous becomes clear also at a later point when Hall, who is a very masculine and a definitely 
heterosexual character, is reflecting on sexuality in a bar while he looks at a female waitress, and asks himself about the meaning of sex. He reveals that he had enjoyed the physical aspects of having sex with a man: "I had adored being the adored male...I had loved it -- the adoration, the warm mouth, the tight ass, the fact that nothing at all was demanded of me except that I shoot my load, which I was very, very happy to do" (309). Hall's bisexuality suggests that it is not important who has sex with whom. The degrading feeling stems from considerations that "I had used somebody merely as a receptacle and had allowed myself to be used merely as a thing" (309) and this occurs in the absence of love between men and women, as well as between men and men, in the novel and in life. Through contemplating these experiences Hall grows and is able to develop understanding and tolerance for his brother's homosexuality and thus encourages Jimmy's and Arthur's relationship. Hall wonders for the first time about love. Love, he concludes, assumes many forms and the acceptance and commitment to it requires strength. ${ }^{17}$ Sexuality is one significant part of love and it takes on beauty, regardless of the gender of the participants, when it involves love. ${ }^{18}$ Arthur's and Jimmy's relational bliss -- although their relationship is the longest homosexual relationship ever depicted in Baldwin's novels -- is only temporary and therein lies the complexity of Baldwin's novel. $\underline{\text { Just Above My }}$ Head is Baldwin's longest and most ambitious novel, and more than Another Country it closely connects the issues of racism and sexism in the American society. Through Arthur Baldwin wants to convey that racial harmony, like 
personal harmony, would come only when there were "no more wretched," as he expressed in the speech "In Search of a Basis for Mutual Understanding and Racial harmony" (1975) (qtd. in Leeming: 335). Arthur's death signifies that love and a relationship are only one of the many sides of life, and that the acceptance of his homosexuality in the small community of family and friends is not enough. Despite his success as a singer, Arthur never feels really accepted for what he is -a black American homosexual artist. He never fully comes to terms with his shame and fear of public condemnation. "All Arthur wanted was for the people he respected to respect him -- the people who had made the music....It was only when he got scared about what they might think of what he had done to their song - our song - that he really started to be uptight about [his and Jimmy's] love “ (553; Baldwin's italics).

Hall is certain that Arthur's and Jimmy's love and their songs gave Arthur a reason to live during that time of their relationship, despite Arthur's increasing troubles. This seems convincing. Arthur dies alone in London, after he has left Jimmy behind in Paris as a consequence of a fight.

Nash points out that Baldwin conveyed a clear enough picture of Arthur as a blameless victim of a society that refuses to hear his song, a society in which "he puts the two words together, black American and hears, at once, the very crescendo of contradiction and the unanswering thunder and truth of history -which is nothing more and nothing less than the beating of his own heart, his song" (437; Baldwin's italics). Arthur furiously told his French lover, Guy, in 
Paris that the root of the problem lies in the truth of history which is that "every single one of you can call me nigger, me and my mama and my daddy and my brother and my sister and my daughter and my son" (475). Thus, Arthur's life is ultimately shattered by the attitudes of his audience -- the symbol for society -through its non-acceptance of Arthur's race and Arthur's sexuality. Arthur is not like the white George Michael, who could sustain his fame despite, or perhaps because of his homosexuality in the early 1980s. Arthur carries the burden of the doubly oppressed and Baldwin, in my opinion, wants to convey through his character Arthur his own complicated position of a black homosexual artist.

Sherley Anne Williams in her essay, "The Black Musician: The Black Hero as Light Bearer," ${ }^{19}$ explains that for Baldwin the musician is the archetypal figure whose referent is black lives, black experiences, and black deaths. "He is the hope of making it in America and the bitter mockery of never making it well enough to escape the danger of being black, the living symbol of alienation from the past and hence from the self and the rhythmical link with the mysterious ancestrous past" (147). William notes that the Baldwin blues hero attempts to survive his anger and alienation through his music. Arthur has carried his music into the secular world, from gospel to blues. However, his self-image is too fragile to withstand the sense of shame about the direction his singing had taken and shame about his relationship with Jimmy. Arthur's death is the result of drugs and alcohol, which caused a heart failure. This is the medical cause. In reality, Jimmy says, "Arthur got hurt, trapped, lost somewhere" (553) between his 
private life and the demands of the public. In the long run he is too vulnerable and too susceptible to the judgment of others. Arthur loses the struggle to "love right" and "to live right" as he sang about in his song. Arthur fails to see in himself what his nephew Tony sees, that "he was a crazy, beautiful cat" (37). Arthur himself is his most critical judge. Hall reveals that Arthur did not possess the larger apprehension demanded by their song,

\section{Lord knows,}

I've got to stop.believing in all your lies, (555; Baldwin's italics)

which again contains Baldwin's sharp criticism that we are the builders of our doom, if we base our own judgment on the "world's indifference" (555), which is built upon conformity. Baldwin, being himself a public figure, always struggled to balance the demands of the public and his private desires. Suicide attempts, lots of alcohol and cigarettes, and years spent outside of America evidence that it was not an easy battle for Baldwin himself, who died of cancer at the age of sixty three.

Hall's story is in itself a song written in the blues style (Nash 110). As Nash explains, loving and being loved are at the heart of the blues affirmation. Thus, Hall's song celebrates all types of love: homosexual, heterosexual, familial, and platonic (111). Although he expresses his sorrow at Arthur's death, his narrative conveys that the joy of loving is worth almost any pain that will follow. 
Through this pain Hall comes to comprehend and appreciate his own happiness; the fact that he is "happy with [Ruth], simply" (23); that he adores his two children, and enjoys the close friendship to Julia and Jimmy. Hall admits that "[he] never knew that [he] could be happy. It never occurred to [him]; [he] had never seen it" (23). He says that in this "fucked-up" world he has not known anyone who was happy. Yet, the apprehension of Arthur's story and his pain have helped Hall to "thank God...come out the wilderness" (24) and see the happiness which is close at hand, although the world is full of agony and misery.

Through Arthur's life and destiny the fates of Hall, Jimmy, Julia, Ruth, Tony, and Odessa have become intrinsically connected. The greatness of Baldwin's characters, in particular, in Just Above My Head, lies in that they are capable of loving everybody. Their love for Arthur -- a brother's love, a sister's love, a lover's love, and familial love -- unites them forever. Arthur is a redemptive figure because his fate creates strong ties among the characters of this small black community. His life and death qualify as a small triumph because they show the acceptance of the Afro-American homosexual Arthur within his own small group and thus makes the characters aware of "the relationship that Negroes bear to one another, that depth of involvement and unspoken recognition of shared experience which creates a way of life" (Leeming 324).

Lovers in Baldwin's fiction are never at peace because he himself was never at peace. He always experienced the ongoing struggle in the world of an artist, an intellect, a homosexual, and an Afro-American and projected much of 
the agony resulting from these roles onto Arthur. Yet, Baldwin was like Arthur in Just Above My Head -- out of his pain he made something not only for his, but for all people and this symbolizes, in my opinion, Baldwin's redeeming powers on a large national and international scale. 


\section{CHAPTER VI}

\section{CONCLUSION: JAMES BALDWIN -- BALANCING THE PARADOX}

The patterns of James Baldwin's novels-- Go Tell It On the Mountain,

Giovanni's Room, Another Country, and Just Above My Head are all comprehensible in light of his own life. ${ }^{20}$

Baldwin poured himself into John Grimes who looked to the church as a stratagem to protect himself from himself and from the sexual guilt which had begun to overtake him in his fourteenth year. The question of sexual dishonesty -- Baldwin almost married a black woman named Grace when he was twenty two -- and his close relationship to Lucien Happersberger, a Swiss whom Baldwin met in Paris, laid the foundation for Giovanni's Room. In Another Country the character of Rufus is built after Eugene Worth, a young Afro-American who was Baldwin's great love in the early 1940s. Eugene, like Rufus, committed suicide by throwing himself off the George Washington Bridge in December 1946. Worth was evidently heterosexual, and Baldwin, for fear of losing him, never admitted his sexual attraction to him, even when Worth obliquely confessed that he might be in love with Baldwin. Baldwin regretted for the rest of his life that he did not see that Worth's "confession" was actually a plea and that if he had had a higher self-esteem back then he might have saved Worth. Lastly, the brother motif in Just Above My Head took much of its energy from Baldwin's close relationship with his 
brother, David. And Arthur Montana, who is named after James Baldwin's middle-name, Arthur, is a reflection of Baldwin himself: the artist who translates his pain into art for his people. Baldwin once said that "the only reason to try to become a writer is not to tell the world how I've suffered...but [as] an act of 'I love you'”(qtd. in Leeming: 334).

Prior to working on Just Above My Head Baldwin wrote in a letter to his brother, David, that the characters he had created in his novels had somehow taken some of the weight off him. He admits that writing Another Country, Go Tell It On the Mountain, and Giovanni's Room had demanded great personal costs of him, but his survival seemed to depend on what he wrote. Always very critical of himself, Baldwin considered segments of his first three novels as badly written, even "pompous." Re-examining them, he wondered at times if he had any idea of who he was. This agonizing search for an identity -- the struggle of finding a position as a spokesman, a writer, and a homosexual in the American scene --which, in my opinion, he never quite resolved during his life is mirrored in "Freaks and the American Ideal of Manhood" (1985) ${ }^{21}$, Baldwin's only essay in which he directly deals with the issue of homosexuality. There he points out that questions such as "Do you really like your mother?" in the 1960s did not cause him to wonder about himself or his mother but about the person asking the question:

And perhaps because of such questions, I was not even remotely tempted by the possibilities of psychiatry or psychoanalysis. For one thing, there were too many schools -- Freud, Horney, Jung, Reich (to suggest merely the tip of that iceberg) -- and, for another, it seemed to me that anyone 
who thought seriously that I had any desire to be "adjusted" to this society had to be ill; too ill...to be trusted.

I sensed, then -- without being able to articulate it -- that this dependence on a formula for safety, for that is what it was, signaled a desperate moral abdication. People went to the shrink in order to find justification for the empty lives they led and the meaningless work they did. (686)

Clearly, Baldwin's life was anything but empty, and his work has made him one of the great Afro-American writers of this century. He never believed in safety, having himself chosen the risky path, and in all his novels he delineates that the pursuit of safety, this striving to conform, prevents happiness. Yet, as I have attempted to illustrate, one can witness that Baldwin's personal search for an identity as a homosexual AfroAmerican writer was painful and characterized by his lifelong struggle between the witness-prophet and the lonely man longing for love. Chasing his entire life the great love of his life, which he never really found, he demonstrates in his novels that happiness is transitory and often associated with France.

This is why, I think, that even as late as 1985, Baldwin was not quite clear about himself in terms of the public and the private person. Surely, I do believe that he did not buy into any psychological ideas personally, yet he affirmed them in his earlier novels as I have shown. However, instead of telling a psychiatrist about his agony of being black and homosexual and thus of carrying the burden of the doubly oppressed, he comprehended it through his writing. This decision cost him much agony, a few suicide attempts, and many years of living abroad to turn his anguish into a weapon. 
His novels, then, represent an expression of his growth; they symbolize how Baldwin had come to accept himself as a black homosexual writer and to integrate his homosexuality into his novels. Each of the novels I have discussed illustrates part of this complicated birth -- hesitation, anguish, elevation of homosexuality, and acceptance of its naturalness.

Baldwin through his "dilemma" knew that racism and sexism are closely entwined. He saw the danger of artificial constructs like "the Negro" or "the homosexual" which did not permit any genuine human interaction. He knew that racism cannot not cease as long as sexism exists. His life had taught him that [t] he American ideal, then, of sexuality appears to be rooted in the American ideal of masculinity. This ideal has created cowboys and Indians, good guys and bad guys, punks and studs, tough guys and softies, butch and faggot, black and white. It is an ideal so paralytically infantile that it is virtually forbidden -- as an unpatriotic act -- that the American boy evolve into the complexity of manhood. (Price of the Ticket 678; Baldwin's italics)

Baldwin's big piercing eyes had looked behind the shallowness of this ideal, and he developed a new definition of manhood that is marked by the capacity to transcend the ordinary and the ability to love regardless of race, religion, gender, or sexuality. Having experienced loneliness and a constant yearning for love throughout his life, Baldwin felt obliged to criticize America -- the country he loved so much -- for the falseness of its morality which produces isolation, alienation, and hostility. Through his criticism he 
demonstrated that he never gave up his belief in America becoming "another country," a better country. Unfortunately, Baldwin did not live long enough to witness that some of his dreams have come true. Through courageous people like him many Americans have learned to look beyond clichés and to believe first and foremost in humanity and equality

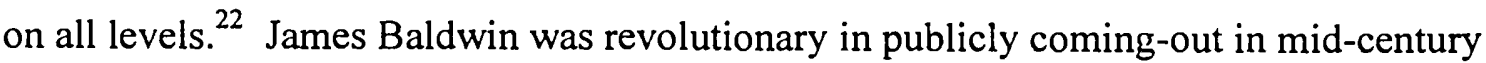
America and he displayed courage and a foresight which can command only the highest respect. 
NOTES

${ }^{1}$ SED is the acronym for Sozialistische Einheitspartei Deutschlands (United Socialist Party of Germany). This party was instituted with the foundation of the German Democratic Republic in 1949. It was called 'United Party' because the leaders of the former KPD (Communist Party of Germany) and the SPD (Socialist Party Of Germany) agreed upon establishing one powerful political party which would control the political, economic, and social life in the GDR.

${ }^{2}$ Günther Grau is the author of the book Homosexualität in der NS-Zeit (Homosexuality during the Nazi era).

${ }^{3}$ Similar to Nazi ideology that homosexuality could harm the German nation, SED officials feared that gay and lesbians could damage the morality of its citizens. The Ministry of Justice proclaimed in 1955, that the danger of homosexuality consists in its threat to the clean and pure sexual up-bringing of, in particular, the youth.

${ }^{4}$ Summers reports that Kinsey's data on homosexuality was very startling. It revealed that $37 \%$ of American males had had significant homosexual experience, that $12 \%$ were predominantly homosexual for at least a three-year period in their lives, and that $4 \%$ were exclusively homosexual as adults (24).

${ }^{5}$ Summer declares that the political agenda of the new gay movement included the repeal of laws criminalizing homosexual activity, the modification of public policies that discriminate against lesbians and gays, the guarantee of equal protection under the law, the combating of harassment and defamation based on sexual orientation, the recognition of gay and lesbian relationships, and the education of the public as to the meaning of the homosexual experience (Summers 16).

${ }^{6}$ A. Billy S. Jones was a civil rights activist and had in the past leadership roles with the National Coalition of Black gays.

${ }^{7}$ David Bergman arrives at this conclusion through Baldwin's remark given in an interview with Richard Goldstein: "Giovanni's Room is not really about homosexuality. It's about what happens to you if you're afraid to love anybody. Which is more interesting than the question of homosexuality" (Qtd. in James Baldwin: The Legacy, ed. Quincey Troupe, 174).

${ }^{8}$ See also my explanations in Chapter III, "The Bridge to Giovanni's Room."

${ }^{9}$ His father has always told John that his face was ugly. 
${ }^{10} \mathrm{John}$, afraid to endanger the relationship, knows that he cannot speak to his mother about his awakening feelings.

"It seems that in the Store Front church, as described in the novel, the people leave their sins behind and assume holiness and purity. The outside world is full of dirt, sins, and sex; the church is a temporary sanctuary. John's father is the best example of the paradox. He committed adultery, impregnated a woman, and though involuntarily, killed her. He also does not treat his stepson as he promised he would do. Yet, he is one of the saints and very respected in the church.

12 Based on Sherry Turkle's book, Psychoanalytic Politics, I tried to explain in Chapter 1 the willful acceptance of psychoanalysis in America as a consequence of the general belief in conformism.

${ }^{13}$ During Hella's absence, David felt that he needed an affirmation that he could still perform sexually with a woman. This is why he goes to bed with Sue; yet he does not enjoy it and realizes afterwards that his "problem" was not a physical one.

${ }^{14}$ David says about his father that he was frightened and afraid at David's development; afraid because he thought that he might have done something wrong in David's up-bringing. Yet, David admits that he "maneuvered [his ] father so well" (30) that he was always able to make him believe that everything was all right.

${ }^{15}$ In particular, in Another Country and Just Above my Head Baldwin makes in my opinion clear references to Freudian theory and psychoanalysis. Cass Silenski refers to the Oedipal triangle when she asks Eric in Another Country: "That's not the usual pattern, is it?...I mean, from what we are told, most men with a sexual bias toward men love their mothers and hate their fathers" (245). Jimmy in Just Above my Head laments that "[t]hey want you to believe that it's 'psychological' - that we are psychological" (552; Baldwin's italics), which means, according to psychoanalytic theory, that homosexuality is a mental disease which is curable.

Moreover, in his essay, "Here Be Dragons" (1985), Baldwin articulates his knowledge of psychoanalytic theory and his disbelief in it.

${ }^{16}$ The heterosexual relationships in the novel might be interpreted as an antiwomen rhetoric employed by Baldwin. However, I have three considerations which undermine this line of argument. First, in his short story, "Come Out the Wilderness" (1958), Baldwin depicted with an incredible sensitivity and insight a viable third person female narrator. Second, a closer examination of the heterosexual relationships [which I omitted because it is not relevant to my reading] would show that these relations more than by sexuality are strained by the issue of race and racism. My third consideration is that Cass undergoes an emancipation and is in general very positively described. 
17 This strength of accepting love in any form and committing to it is a quality David in Giovanni's Room lacked and thus was faced with loneliness.

${ }^{18}$ The link Baldwin establishes between sexuality and love is evident at another point in the story when Red and Peanut, the other two members of the Trumpets of Zion quartet, share a moment of physical communion. The plot indicates that they are basically heterosexual. Yet, one warm summer night Red asks Peanut to help him to relax and they manually stimulated each other on the roof of a house under the sky. This, at least for Peanut, completely new experience makes him very happy because he sees this act as another kind of gift he could give to his best friend, Red, to celebrate their friendship (413).

Baldwin's powerful and rhythmic language in this passage and the pain with which Peanut then mourns the loss of his best friend because he turned into a junkie, again stresses the importance of what was perceived -- in this case by Peanut -- as an act of friendship. Red and Peanut at this moment do not care about any moral prescriptions but just follow their emotions, which makes this act pure and meaningful to them and to the reader.

19 reprinted in James Baldwin: A Collection of Critical Essays, ed. Keneth Kinnamon.

${ }^{20}$ Names of people, facts, and dates in this chapter are taken from David Leeming's biography, James Baldwin. Ticket.

${ }^{21}$ Rpt. as "Here Be Dragons" in Baldwin's essay collection, The Price of the

22 Mass public political activities such as protestations against Measures 9 and 13 in 1992 and 1994 evidence, in my opinion, a progression toward the recognition of homosexuality as a normal variation of human sexuality on a broad social level and the people's awareness of the danger of any discrimination. 


\section{BIBLIOGRAPHY}

Adams, Stephen D. "James Baldwin." The Homosexual as Hero in Contemporary Fiction. New York: Barnes \& Noble, 1980.

Als, Hilton. "Fathers and Sons." Village Voice 12 Jan. 1988: 35+.

Auchincloss, Eve and Nancy Lynch. "Disturber of the Peace: James Baldwin." Rpt. in The Black American Writer Vol. 1. Ed. C. W. E. Bigsby. Florida: Everett/ Edwards, 1969.

Austen, Roger. Playing the Game: The Homosexual Novel in America. Indianapolis: Bobbs-Merril, 1977.

Baldwin, James. Another Country. 1962. New York: Dell publishing Co., 1970.

---. The Fire Next Time. New York: Dial Press, 1963.

---. Giovanni's Room. 1956. New York: Dell Publishing Co., 1988.

--.. Go Tell It On the Mountain. 1952. New York: Signet, 1963.

--.. Just Above My Head. New York: Dell Publishing Co., 1978.

---. Nobody Knows My Name. More Notes of a Native Son. New York: Dial. Press, 1961.

---. Notes of a Native Son. 1955. Boston: Beacon Press, 1963.

---. The Price of the Ticket. New York: St. Martin's/ Marek. 1985.

Balliet, Whitney. "Wrong Pulpit." New Yorker 4 Aug. 1962: 69 - 70.

Ballot Measure 9. Dir. Heather MacDonald. Oregon Tape Projects, 1994.

Beam, Joseph, ed. In The Life: A Black Gay Anthology. Boston: Alyson Publications, Inc., 1986.

Bergman, David. "The African and the Pagan in Gay Black Literature." Rpt. in Sexual Sameness. Textual Differences in Lesbian and Gay Writing. Ed. Joseph Bristow. London: Routledge, 1992.

---. Gaiety Transfigured: Gay Self-Representation in American Literature. Madison: The University of Wisconsin Press, 1991. 
Bieber, Irving. Homosexuality: A Psychological Study. New York: Vintage, 1962.

Bloom, Harold, ed. Modern Critical Views: James Baldwin. New York: Chelsea, 1986.

Bone, Robert A. The Negro Novel in America. London: Yale UP, 1969.

Bristow, Joseph, ed. Sexual Sameness. Textual Differences in Lesbian and Gay Writing. London: Routledge, 1992.

Bruck, Peter. "Dungeon and Salvation: Biblical Rhetoric in James Baldwin's Just Above My Head. repr. in History and Tradition in Afro-American Culture, ed. Guenter H.Lenz. Frankfurt/ New York: Campus Verlag, 1984.

Bryant, Anita. The Anita Bryant Story: The Survival of Our Nation's Families and the Threat of Militant Homosexuality. Old Tappan, N.J.: Revell, 1977.

Campbell, James. Talking at the Gates: A Life of James Baldwin. New York: Viking, 1991.

Cederstrom, Lorelei. "Love, Race and Sex in the Novels of James Baldwin." Mosaic 17.2 (1984): $175-188$.

Cleaver, Eldridge. "Notes on a Native Son." Ramparts 5.1 (1966): 51 - 56.

Rpt. in Soul On Ice. New York: Dell Publishing Co., 1968.

Cooke, Michael. Modern Black Novelists. Englewood Cliffs, NJ: Prentice-Hall, 1971.

Crouch, Stanley. "The Rage of Race." Village Voice 12 Jan. 1988: 35+.

Cruttwell, Patrick. "Fiction Chronicle." Hudson Review 15 (1963): 589 - 98.

Dailey, Peter. "Jimmy." The American Scholar 63 (1994): 102 -1 11.

DeGout, Yasmin Y. "Dividing the Mind: Contradictory Portraits of Homoerotic Love in Giovanni's Room." African American Review 26 (1992): 425 435 .

Draper, James P., ed. Black Literature Criticism. 2 vols. Detroit: Gale, 1992. 
Eckman, Fern Marja. The Furious Passage of James Baldwin. New York: M. Evans \& Company, 1966.

Erikson, Erik. Identity: Youth and Crisis. New York: Norton, 1968.

Finn, James. “The Identity of James Baldwin.” Commonweal 77(1962): 113.

Fuss, Diana. Essentially Speaking: Feminism, Nature, and Difference. New York: Routledge, 1989.

Gates, Henry Louis Jr. “ The Fire Last Time: What James Baldwin Can and Can't Teach America." The New Republic 206 (1992): 37-43.

Giles, James R. "Religious Alienation and Homosexual Consciousness." College English 36 (1974/75): $369-380$.

Gilman, Richard. Rev. of Just Above My Head, by James Baldwin. New Republic Nov. 1979: 30.

Goldstein, Richard. "“Go the Way Your Blood Beats': An Interview with James Baldwin." 1984. Rpt. in James Baldwin: The Legacy, ed. Quincey Troupe. New York: Simon \& Schuster, 1989.

Grau, Günter. Homosexualität in der NS-Zeit. Frankfurt: Fischer Taschenbuch Verlag, 1995.

Hogan, William. "Baldwin's Comment on a Sub-Culture." San Francisco Chronicle 28 June 1962: 35.

Ivy, James. "The Faerie Queens." The Crisis 64 (1957): 123.

James Baldwin: The Price of the Ticket. Dir. Karen Thorson. California Newsreel, 1990.

Kinnamon, Keneth, ed. James Baldwin: A Collection of Critical Essays. Englewood Cliffs, NJ: Prentice-Hall, 1974.

Kinsey, Alfred et al. Sexual Behavior and the Human Male. Philadelphia: W. B. Saunders, 1948.

Kosofsky Sedgwick, Eve. Between Men: English Literature and Male Homosocial Discourse. New York: Columbia UP, 1985. 
---. Epistemology of the Closet. Berkely: University of California Press, 1990.

Krim, Seymour. "The Troubles He's Seen." Rev. of "Going to Meet the Man," by James Baldwin. Book Week 7 Nov. 1965: 5.

Lee, Dorothy H. "The Bridge of Suffering." Callaloo 6.2 (1983): 92 - 99.

Leeming, David. James Baldwin. A Biography. New York: Alfred A. Knopf, 1994.

Levin, James. The Gay Novel in America. New York: Garland, 1991.

Lilly, Mark. Gay Men's Literature in the Twentieth Century. New York: New York UP, 1993.

---, ed. Lesbian and Gay Writing: An Anthology of Critical Essays. Philadelphia: Temple UP, 1990.

Littlejohn, David. Black on White: A Critical Survey of Writing By American Negroes. New York: Viking, 1966.

Lunden, Rolf. "The Progress of a Pilgrim." Studia Neophilologica 53 (1981): $113-126$.

Lynch, Michael. "Beyond Guilt and Innocence: Redemptive Suffering and Love in Baldwin's Another Country." Obsidian II: Black Literature in Review 7.1-2 (1992): 1 - 18.

Macebuh, Stanley. James Baldwin: A Critical Study. New York: The Third Press, 1973.

MacInnes, Colin. "Dark Angel: The Writings of James Baldwin." Encounter 21 (1963): $22-23$.

Moore, Henry Thornton, ed. Contemporary American Novelists. Carbondale: Southern Illinois UP, 1964.

Mootry, Maria K. "Baldwin's Go Tell It On the Mountain." Explicator Winter 1985: $50-52$.

Mossman, James. "Race, Hate, Sex, and Colour: A Conversation with James Baldwin and Colin MacInnes." Encounter 28 (1965): 55 - 60. 
Nash, Julie. "“A Terrifying Sacrament': James Baldwin's Use of Music in Just Above My Head." MAWA-Review 7.2 (1992): 107 - 111.

Nelson, Emmanuel S. "Critical Deviance: Homophobia and the Reception of James Baldwin's Fiction." Journal of American Culture 14 (1991): 91 96.

---. "The Novels of James Baldwin: Struggles of Self-Acceptance." Journal of American Culture 8 (1985): $11-16$.

Nordell, Roderick. "Old and New Novels on Racial Themes." Christian Science Monitor 19 July 1962: 6.

O'Daniel, Therman B., ed. James Baldwin: A Critical Evaluation. Washington, D.C.: Howard UP, 1977.

Porter, Horace. Stealing the Fire: The Art and Protest of James Baldwin. Middletown: Wesleyan UP, 1989.

Pratt, Louis H. James Baldwin. Boston: G. K. Hall \& Co., 1978.

“Reine Erziehung." Der Spiegel 26 (1996): 76 - 77.

Rolo, Charles. Rev. of Giovanni's Room, by James Baldwin. Atlantic Monthly 198 (December 1956): 98.

Root, Robert. Rev. of Another Country, by James Baldwin. Christian Century 79 (1962): $1354-55$.

Rowden, Terry. "A Play of Abstractions: Race, Sexuality, and Community in James Baldwin's Another Country." The Southern Review 29 (1993): 41 -50 .

Sinfield, Alan. Cultural Politics - Queer Reading. Philadelphia: University of Pennsylvania Press, 1994.

Smith, Michael J., ed. Black Men/ White Men. San Francisco: Gay Sunshine Press, 1983.

Standley, Fred L. and Louis H. Pratt, eds. Conversations with James Baldwin. Jackson: UP of Mississippi, 1989. 
Summers, Claude J. Gay Fictions: Wilde to Stonewall: Studies in a Male Homosexual Tradition. New York: Continuum, 1990.

Sylvander, Carolyn Wedin. James Baldwin. New York: Frederick Ungar Publishing Co., 1980.

Traylor, Eleanor W. "I Hear Music in the Air: James Baldwin's Just Above My Head." Rpt. in James Baldwin: The Legacy, ed. Quincy Troupe. New York: Simon \& Schuster, 1989.

Turkle, Sherry. Psychoanalytic Politics. New York: Basic Books, 1978.

Waldrep, Shelton. "'Being Bridges': Cleaver/ Baldwin/ Lorde and AfricanAmerican Sexism and Sexuality." Rpt. in Critical Essays: Gay and Lesbian Writers of Color. Ed. Emmanuel S. Nelson. New York: Haworth Press, 1993.

Warren, Nagueyalti. "The Substance of Things Hoped For: Faith in Go Tell It On the Mountain and Just Above My Head." Obsidian II: Black Literature in Review 7.1-2 (1992): 19 - 32.

Washington, Bryan R. The Politics of Exile. Ideology in Henry James, F. Scott Eitzgerald, and James Baldwin. Boston: Northeastern UP, 1995.

Weatherby, W. J. James Baldwin: Artist on Fire. New York: Donald I. Fine, 1989.

West, Anthony. Rev. of Giovanni's Room, by James Baldwin. New Yorker 32 (November 1956): $219-224$.

White, Edmund. "James Baldwin Overcomes." Bookworld - The Washington Post 23 Sep. 1979: 5+. 